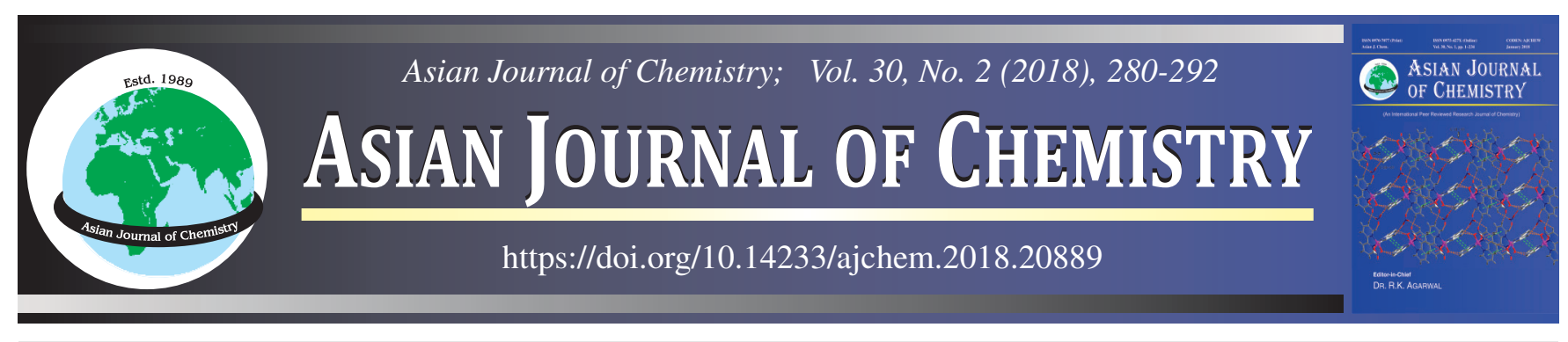

\title{
Synthesis, Spectral, Thermal and Biological Studies of Some Metal Complexes Derived from Heterocyclic Mono Azo Dye Ligand 2'[(2'-Hydroxy-4-methyl phenyl)azo]imidazole
}

\author{
Khalid J. Al-AdileE* and SAad A. Atyha
}

Department of Chemistry, College of Education, University of Al-Qadisiyah, Diwaniya 1753, Iraq

*Corresponding author: Tel: +964 7811596576; E-mail: khalid.jawad@qu.edu.iq; khalidke_1962@yahoo.com

\begin{abstract}
A new hetrocyclic mono azo dye ligand 2' [2'-(1-hydroxy-4-methyl phenyl)azo]imidazole (HMePAI) was prepared by reaction between diazonium chloride salt solution of 2'-amino-4-methyl phenol with imidazole in alkaline ethanolic solution. Nine metal complexes with $\mathrm{Cr}(\mathrm{III}), \mathrm{Mn}(\mathrm{II}), \mathrm{Fe}(\mathrm{III}), \mathrm{Co}(\mathrm{III}), \mathrm{Ni}(\mathrm{II}), \mathrm{Cu}(\mathrm{II}), \mathrm{Zn}(\mathrm{II}), \mathrm{Cd}(\mathrm{II})$ and $\mathrm{Hg}(\mathrm{II})$ ions were prepared and characterized by analytical and spectral techniques like elemental analysis $(\mathrm{CHN})$, metal contents, molar conductance, magnetic moments, ${ }^{1} \mathrm{H}$ NMR, Mass spectra, infrared, electronic spectral, XRD spectra, SEM and thermal studies (TGA \& DSC). The results indicated that the ligand (HMePAI) behaves as a tridentate in case of 1:2 [metal:ligand] complexes. Investigation of the stereochemistry of metal complexes have octahedral geometry. Biological activity of ligand (HMePAI) and its metal complexes against two types of bacteria, Staphylococcus aureus (Gram-positive) and Escherichia coli (Gram-negative) by agar plate different technique. The biological activity was also conducted by cells viability and cytotoxicity assay on ligand and Ni(II) complex by using the lines of cancerous liver cells of the type HEPG2 and compared with line of the ordinary cells.
\end{abstract}

Keywords: Azo imidazole, Metal complexes, Synthesis and Characterization, Biological activity.

\section{INTRODUCTION}

Azo imidazole dyes have enormous applications in different fields such as polymerization [1], textile [2], leather paper, paint, wood, silk, rubber, plastics, cosmetics operations and coating industries as a dyeing agent [3-6]. It is also used in the pharmaceutical and food industries as a colouring agent [7]. Imidazole ring is an important pharmacophore in drug discovery. Extensive biochemical and pharmacological studies have confirmed that imidazole molecule is associated with a wide range of biological activities including anticancer $[8,9]$, antibacterial [10], antifungal [11], antioxidant [12], antihypertensive [13] and anticoagulant [14], properties. In recent years, there have been important applications of azo dye was permeate into the field of electronic industry as a strong components in the DVD-R (digital versatile disc-recordable) because of its characteristic as stable metal azo dyes. Azo dyes can be coated easily by spin coating method which increases good thermal stability, refractive index [15] and also metal complexes of the azo dyes are having extensive application in electro-photographic toners as charge controlling agents, developers in powder coating materials, electric materials and in electrostatic separation processes, in-ink jets and in colour filters [16-18]. The dyeing ability of the azo dyes depends on the functional group present in the azo dyes compounds, such as hydroxyl, carboxylic acid, halogens, esters and amines $[19,20]$. An important uses of azo imidazole compounds used analytical reagents for solvent extraction to determination of some metal ions $[21,22]$. The heterocyclic azo imidazole compounds have important role in spectral determination field to determine the trace amount of elements especially transition metal ions and heavy metals because of high sensitivity and selectivity [23,24].

The present work describes the synthesis and spectral characterizations of 2'[2'-(1-hydroxy-4-methyl phenyl)azo]imidazole $(\mathrm{HMePAI}=\mathrm{HL})$, containing phenolic-OH function and imidazole moiety. The heterocyclic mono azo dye ligand and its metal complexes were studied by various spectral analysis and screened for their biological activities. As well as the study of ligand and $\mathrm{Ni}$ (II) complex of prescription drug anticancer by using the lines of cancerous liver cells of the type HePG2 and compared with line of the ordinary cells.

\section{EXPERIMENTAL}

All other organic chemicals, solvents and inorganic salts were available from multiple companies, Fluka, B.D.H, Merck, Scharin, Sigma and Alderich and used without further purification. 
Microanalytical data (CHN) were collected on EA 300 CHNS Elemental analyzer. Mass spectra were recorded on a Shimadzu Agilent Technologies 5973 at 70 and MSD energy using a direct insertion probe (Acq method $10 \mathrm{~W}$ energy) at 90-110 ${ }^{\circ} \mathrm{C} .{ }^{1} \mathrm{H}$ NMR spectra were recorded using a Bruker 400 MHz spectrophotometer in DMSO- $d_{6}$ using TMS as an internal reference. Infrared spectra were taken on Shimadzu 8400 S FTIR spectrophotometer with samples prepared as $\mathrm{KBr}$ pellets. Electronic spectral studies were performed on UV-visible. T80PG spectrophotometer in absolute ethanol $\left(10^{-3} \mathrm{M}\right)$ in the range (200-1100) nm. The metal contents were determined by using atomic absorption technique by Shimadzu AA-6300. TGA, DSC and DTG analysis were measured with England PL-TG using Rheometric scientific TGA-1000. SEM images were taken using micrograph kyky 3200. X-ray diffraction was measured using Bestec Germany Alminium anode model X-pertpro, wavelength of X-ray beam $\left(\mathrm{Cu} \mathrm{K}_{\alpha}\right) 1.54 \AA$, Anode material = $\mathrm{Cu}$, the Voltage $=40 \mathrm{KV}$ and current $=30 \mathrm{~mA}$. Molar conductivity measurements were recorded on conductivity bridge model $31 \mathrm{~A}$ in dry DMF $\left(10^{-3} \mathrm{M}\right)$ solution at room temperature. Magnetic susceptibility for prepared metal complexes was measured on a Burker Magnet (BM) and the diamagnetic correction was made by Pascal's constants at room temperature by using faraday method. The $\mathrm{pH}$ of solutions was measured on a Philips pw $9421 \mathrm{pH}$ meter $( \pm 0.001)$. The chloride ion contents in $\mathrm{Cr}$ (III), $\mathrm{Fe}(\mathrm{III})$ and $\mathrm{Co}(\mathrm{III})$ complexes determined as per Vogel's procedure [25] and $\mathrm{AgNO}_{3}$ solution.

Synthesis of 2' [2'-(1-hydroxy-4-methyl phenyl)azo]imidazole (HL): The new mono heterocyclic azo dye ligand (HMePAI) (Scheme-I) has been synthesized by the diazotization coupling by flowing method proposed by Al-Adilee et al. $[24,26]$ with some modification. 2'-Amino-4-metheyl phenol $(1.23 \mathrm{~g}, 0.01 \mathrm{~mol})$ was dissolved in $4 \mathrm{~mL}$ conc. $\mathrm{HCl}$ and $25 \mathrm{~mL}$ distilled water and cooled to $0{ }^{\circ} \mathrm{C}$ sodium nitrite $(0.75 \mathrm{~g}, 0.01$ mol) was dissolved in $20 \mathrm{~mL}$ distilled water and cooled to
$0-5{ }^{\circ} \mathrm{C}$. The diazotized solution was added drop-wise with constant stirring to imidazole $(0.68 \mathrm{~g}, 0.01 \mathrm{~mol})$ dissolved in $100 \mathrm{~mL}$ ethanol and $18 \mathrm{~mL}$ of $7 \%$ sodium hydroxide with cooling and stirring continuously for $1 \mathrm{~h}$ at $0-3{ }^{\circ} \mathrm{C}$ in ice-bath and allowed to stand overnight and acidified with dilute $\mathrm{HCl}$ to $\mathrm{pH}=6.0$. The precipitate was filtered off and washed several times with cold distilled water and recrystallized twice from hot ethanol and then dried in oven at $50{ }^{\circ} \mathrm{C}$ for several hours and stored in a desiccator over anhydrous $\mathrm{CaCl}_{2}$. The yield was $81 \%$ of dark red crystals and melting point found to be $130{ }^{\circ} \mathrm{C}$. The purity was confirmed by the elemental analysis and TLC techniques.

Synthesis of metal complexes: The metal complexes were prepared using corresponding metal chlorides and azo dye ligand (HMePAI) at 1:2 [M:L] molar ratio. An ethanolic solution $(0.404 \mathrm{~g}, 0.002 \mathrm{~mol})$ was dissolved in $50 \mathrm{~mL}$ of azo dye ligand and (0.001 mol) of $\mathrm{Cr}(\mathrm{III}), \mathrm{Mn}(\mathrm{II}), \mathrm{Fe}(\mathrm{III}), \mathrm{Co}(\mathrm{III}), \mathrm{Ni}(\mathrm{II})$, $\mathrm{Cu}(\mathrm{II}), \mathrm{Zn}$ (II), $\mathrm{Cd}$ (II) and $\mathrm{Hg}$ (II) chlorides dissolved in $40 \mathrm{~mL}$ hot buffer solution (ammonium acetate) at $\mathrm{pH}=7.0$ for each metal ions was refluxed on water bath for 1-2 $\mathrm{h}$. The separated solid metal complexes were filtered off, washed with little warm ethanol $(5 \mathrm{~mL})$ to remove any traces of unreacted material and wished with distilled water. The metal complexes obtained were finally dried in oven at $60{ }^{\circ} \mathrm{C}$ to several hours and kept under vacuum desiccators over fused $\mathrm{CaCl}_{2}$. The $\%$ yield, m.p., molecular formula, m.w., colour and element analysis data (CHN) of azo dye ligand and its metal complexes are collected in Table-1.

\section{RESULTS AND DISCUSSION}

Characterization of azo dye ligand and its metal complexes: The mono heterocyclic azo dye ligand (HMePAI) was dark red crystals but the metal complexes of this ligand vary in colour depending on metal ions. The experimental result of the elemental analysis of the prepared azo dye ligand and its metal complexes are in good agreement with theoretical expec-<smiles>Cc1ccc(O)c(N)c1</smiles>

2-Amino-4-methyl phenol<smiles></smiles>

Diazonium salt


$\mathrm{pH}=6.0$<smiles></smiles>

Diazonium salt<smiles>Cc1ccc(O)c(/N=N/c2ncc[nH]2)c1</smiles>

(HMePAI)

Scheme-I: Syntheic pathway of heterocyclic azo dye ligand 2' [2'-(1-hydroxy-4-methyl phenyl)azo]imidazole $(\mathrm{HMePAI}=\mathrm{HL})$ 
TABLE-1

ANALYTICAL AND PHYSICAL DATA OF AZO DYE LIGAND AND ITS METAL COMPLEXES

\begin{tabular}{|c|c|c|c|c|c|c|c|c|}
\hline \multirow{2}{*}{ Compound } & \multirow{2}{*}{ Colour } & \multirow{2}{*}{$\begin{array}{l}\text { m.p. } \\
\left({ }^{\circ} \mathrm{C}\right)\end{array}$} & \multirow{2}{*}{$\begin{array}{l}\text { Yield } \\
(\%)\end{array}$} & \multirow{2}{*}{ m.f. (m.w.) } & \multicolumn{4}{|c|}{ Elemental analysis (\%): Found (calcd.) } \\
\hline & & & & & $\mathrm{C}$ & $\mathrm{H}$ & $\mathrm{N}$ & $\mathrm{M}$ \\
\hline HMePAI & Dark red & 130 & 81 & $\mathrm{C}_{10} \mathrm{H}_{10} \mathrm{~N}_{4} \mathrm{O}(202.21)$ & $59.18(59.40)$ & $4.91(4.98)$ & $27.13(27.71)$ & - \\
\hline$\left[\mathrm{Cr}(\mathrm{L})_{2}\right] \mathrm{Cl}$ & Dark brown & 192 & 78 & $\mathrm{C}_{20} \mathrm{H}_{18} \mathrm{~N}_{8} \mathrm{O}_{2} \mathrm{CrCl}(489.86)$ & $49.23(49.04)$ & $3.59(3.70)$ & $23.22(22.87)$ & $10.89(10.61)$ \\
\hline$\left[\mathrm{Mn}(\mathrm{L})_{2}\right]$ & Redish orange & 198 & 63 & $\mathrm{C}_{20} \mathrm{H}_{18} \mathrm{~N}_{8} \mathrm{O}_{2} \mathrm{Mn}(457.35)$ & $52.12(52.52)$ & $4.05(3.97)$ & $24.95(24.50)$ & $12.23(12.01)$ \\
\hline$\left[\mathrm{Fe}(\mathrm{L})_{2}\right] \mathrm{Cl}$ & Brown & 185 & 67 & $\mathrm{C}_{20} \mathrm{H}_{18} \mathrm{~N}_{8} \mathrm{O}_{2} \mathrm{FeCl}$ 493.71) & $48.88(48.65)$ & $3.58(3.67)$ & $22.93(22.69)$ & $11.65(11.31)$ \\
\hline$\left[\mathrm{Co}(\mathrm{L})_{2}\right] \mathrm{Cl}$ & Dark purple & 193 & 74 & $\mathrm{C}_{20} \mathrm{H}_{18} \mathrm{~N}_{8} \mathrm{O}_{2} \mathrm{CoCl}$ (496.80) & $50.71(50.38)$ & $3.67(3.80)$ & $23.67(23.50)$ & $12.48(12.36)$ \\
\hline$\left[\mathrm{Ni}(\mathrm{L})_{2}\right]$ & Olive & 201 & 71 & $\mathrm{C}_{20} \mathrm{H}_{18} \mathrm{~N}_{8} \mathrm{O}_{2} \mathrm{Ni}(461.11)$ & $52.55(52.09)$ & $4.02(3.93)$ & $24.37(24.30)$ & $13.71(12.73)$ \\
\hline$\left[\mathrm{Cu}(\mathrm{L})_{2}\right]$ & Dark green & 195 & 82 & $\mathrm{C}_{20} \mathrm{H}_{18} \mathrm{~N}_{8} \mathrm{O}_{2} \mathrm{Cu}$ (465.96) & $51.72(51.55)$ & $3.77(3.89)$ & $24.38(24.05)$ & $14.07(13.64)$ \\
\hline$\left[\mathrm{Zn}(\mathrm{L})_{2}\right]$ & Brown & 205 & 86 & $\mathrm{C}_{20} \mathrm{H}_{18} \mathrm{~N}_{8} \mathrm{O}_{2} \mathrm{Zn}(467.82)$ & $51.59(51.35)$ & $3.93(3.88)$ & 24.1023 .95 & 14.19 (13.98) \\
\hline$\left[\mathrm{Cd}(\mathrm{L})_{2}\right]$ & Redish purple & 210 & 66 & $\mathrm{C}_{20} \mathrm{H}_{18} \mathrm{~N}_{8} \mathrm{O}_{2} \mathrm{Cd}$ (514.82) & $46.47(46.66)$ & $3.42(3.52)$ & $21.85(21.76)$ & - \\
\hline$\left[\mathrm{Hg}(\mathrm{L})_{2}\right]$ & Redish brown & 200 & 79 & $\mathrm{C}_{20} \mathrm{H}_{18} \mathrm{~N}_{8} \mathrm{O}_{2} \mathrm{Hg}(603.00)$ & $40.36(39.84)$ & $3.07(3.01)$ & $18.83(18.58$ & - \\
\hline
\end{tabular}

tations. The monoazo dye ligand and its metal complexes were soluble in most organic solvents such as methanol, ethanol, acetone, chloroform, pyridine, DMF and DMSO giving stable solutions at room temperature but in soluble in water. However, some physical and analytical data are given in Table-1.

Metal:Ligand ratio: The possible structural formula of prepared metal complexes was studied by molar ratio method at $\mathrm{pH}=7.0$ and optimum concentration at wavelength maximum absorption $\left(\lambda_{\max }\right)$. The solutions of metal complexes increase the intensity of the colours as an approach point of intersection ratio [M:L] and colour continous constant at passing this point which indicates that the metal complexes formed in constant of solution. The metal:ligand [M:L] ratio in all metal complexes was found to form 1:2 chelates. These results are in agreement with values reported for some aryl azo imidazole complexes [24,27].

Molar conductivity measurements: The molar conductance measurements of the prepared metal complexes were measured in the solvent $\mathrm{DMF}\left(10^{-3} \mathrm{M}\right)$ at room temperature are shown in Table-2. The high values of molar conductivity of the $\mathrm{Cr}$ (III), $\mathrm{Fe}$ (III) and $\mathrm{Co}$ (III) complexes indicate that complexes are 1:1 electrolyte with ionic nature but the low values of molar conductivity of metal complexes of $\mathrm{Mn}(\mathrm{II}), \mathrm{Ni}(\mathrm{II}), \mathrm{Cu}(\mathrm{II})$, $\mathrm{Zn}(\mathrm{II}), \mathrm{Cd}(\mathrm{II})$ and $\mathrm{Hg}(\mathrm{II})$ ions indicate that non-electrolytic nature and no chloride ions are present outside the coordination spheres [28,29].

Calculation stability constants: The stability constants ( $\beta$ and $\log \beta$ ) of metal complexes were obtained spectrophotometrically by measuring the absorbance of solution mixture of azo dye ligand and metal ion at $\mathrm{pH}=7.0$ and optimum concentration at fixed wavelength $\left(\lambda_{\max }\right)$. The degree formation of the metal complexes is calculated according to the relationship, $\beta=(1-\alpha) / 4 \alpha^{3} c^{2}, \alpha=\left(A_{m}-A_{s} / A_{m}\right)$, where $A_{s}$ and $A_{m}$ are the absorbance of the partially and fully formed complexes respectively. The stability constants of metal complexes according to the following sequence:

$$
\begin{gathered}
\mathrm{Mn}(\mathrm{II})>\mathrm{Ni}(\mathrm{II})>\mathrm{Fe}(\mathrm{III})>\mathrm{Zn}(\mathrm{II})>\mathrm{Co}(\mathrm{III})> \\
\mathrm{Cr}(\mathrm{III})>\mathrm{Hg}(\mathrm{II})>\mathrm{Cd}(\mathrm{II})>\mathrm{Cu}(\mathrm{II}) .
\end{gathered}
$$

The sequence of metal ions of the first row transition metal with Irving-Williams series of stability constant [30,31].

${ }^{1}$ H NMR spectra: ${ }^{1} \mathrm{H}$ NMR spectra of mono azo dye ligand (HMePAI) and $\mathrm{Ni}$ (II) complex was measured in DMSO- $d_{6}$ as solvent with TMS as an internal reference $(400 \mathrm{MHz})$ and characterized by presence of a low-field. ${ }^{1} \mathrm{H}$ NMR spectrum of azo dye ligand shows a signal at $\delta=12.164 \mathrm{ppm}(\mathrm{S}, 1 \mathrm{H})$ due to the presence of $\mathrm{OH}$-group, a signal at $\delta=10.234 \mathrm{ppm}$ $(\mathrm{S}, 1 \mathrm{H})$ due to the presence of amide $(\mathrm{NH})$ in imidazole ring and a signal at $\delta=9.623 \mathrm{ppm}(\mathrm{S}, 4 \mathrm{H}$ and $5 \mathrm{H})$ protons due to imidazole ring. A signal at $\delta=7.864 \mathrm{ppm}(\mathrm{d}, 3 \mathrm{H}, 5 \mathrm{H})$ and a signal at $\delta=7.123 \mathrm{ppm}(\mathrm{q}, 6 \mathrm{H})$ due to the presence of aromatic protons. The signal at $\delta=2.505-2.513 \mathrm{ppm}(\mathrm{S}, 3 \mathrm{H})$ due to the presence of $\mathrm{CH}_{3}$ group. While a signal at $\delta=1.151-1.238 \mathrm{ppm}$ (S) due to solvent protons $[32,33]$.

The ${ }^{1} \mathrm{H}$ NMR spectrum of Ni(II) complex shows a signal at $\delta=10.046 \mathrm{ppm}(\mathrm{S}, 1 \mathrm{H})$ due to the presence of amide $(\mathrm{NH})$ proton in imidazole molecule while a signal at $\delta=10.023 \mathrm{ppm}$ $(\mathrm{S}, 4 \mathrm{H}$ and $5 \mathrm{H})$ proton due to imidazole ring. A signal at $\delta=$ 7.69-7.731 ppm (m, 3H, 5H) and a signal at $\delta=6.924 \mathrm{ppm}(\mathrm{S}$, $6 \mathrm{H})$ due to the presence of aromatic protons. The signal at $\delta=$

TABLE-2

MOLAR CONDUCTIVITY, STABILITY CONSTANTS VALUES ( $\beta$ AND $\log \beta$ ), OPTIMAL CONCENTRATION,

\begin{tabular}{|c|c|c|c|c|c|c|c|}
\hline Ligand (HMePAI) & Metal ion & $\begin{array}{c}\text { Optimal conc. } \\
\times 10^{-4} \mathrm{M}\end{array}$ & $\begin{array}{c}\text { Maximum } \\
\text { wavelength } \\
\left(\lambda_{\max }, \mathrm{nm}\right)\end{array}$ & $\begin{array}{l}\text { Molar absorptivity } \\
(\varepsilon) \times 10^{3} \\
\mathrm{~L} \mathrm{~mol}^{-1} \mathrm{~cm}^{-1}\end{array}$ & $\begin{array}{c}\text { Molar } \\
\text { conductivity } \\
\left(\mathrm{S} \mathrm{cm}^{2} \mathrm{~mol}^{-1}\right)\end{array}$ & $\begin{array}{c}\text { Stability } \\
\text { constant }(\beta) \\
\left(\mathrm{L}^{2} \mathrm{~mol}^{-2}\right)\end{array}$ & $\log \beta$ \\
\hline \multirow{8}{*}{$\begin{array}{c}\text { Ligand }=\mathrm{HL} \\
(\mathrm{HMePAI}) \\
\lambda_{\max }=431 \mathrm{~nm} \\
\varepsilon=2.84 \times 10^{3} \\
\mathrm{~L} \mathrm{~mol}^{-1} \mathrm{~cm}^{-1} \\
\text { Conc. }=1.75 \times \\
10^{-4} \mathrm{M}\end{array}$} & $\mathrm{Cr}$ (III) & 2.00 & 480 & 9.61 & 78.21 & $12.66 \times 10^{8}$ & 9.10 \\
\hline & $\mathrm{Mn}(\mathrm{II})$ & 1.50 & 447 & 7.78 & 12.28 & $33.30 \times 10^{8}$ & 9.52 \\
\hline & $\mathrm{Fe}(\mathrm{III})$ & 2.25 & 472 & 6.67 & 68.59 & $19.56 \times 10^{8}$ & 9.30 \\
\hline & $\mathrm{Co}(\mathrm{III})$ & 1.75 & 505 & 10.55 & 71.09 & $18.15 \times 10^{8}$ & 9.26 \\
\hline & $\mathrm{Ni}(\mathrm{II})$ & 1.50 & 635 & 3.45 & 11.84 & $24.20 \times 10^{8}$ & 9.38 \\
\hline & $\mathrm{Zn}(\mathrm{II})$ & 1.50 & 476 & 9.11 & 14.66 & $19.50 \times 10^{8}$ & 9.29 \\
\hline & $\mathrm{Cd}(\mathrm{II})$ & 1.50 & 450 & 1.66 & 10.86 & $8.51 \times 10^{8}$ & 8.93 \\
\hline & $\mathrm{Hg}$ (II) & 1.75 & 475 & 9.79 & 12.43 & $9.81 \times 10^{8}$ & 8.99 \\
\hline
\end{tabular}
MAXIMUM WAVELENGTH $\left(\lambda_{\max }\right)$ AND MOLAR ABSORPTIVITY $(\varepsilon)$ OF METAL COMPLEXES 
2.509-2.678 ppm $(\mathrm{S}, 3 \mathrm{H})$ due to the presence of $\mathrm{CH}_{3}$ group and a signal at $\delta=1.233-1.283 \mathrm{ppm}(\mathrm{S})$ due to the solvent.

The signal of proton (-OH group) disappearance in spectrum of $\mathrm{Ni}(\mathrm{II})$ complex indicates hydrogen atom of $-\mathrm{OH}$ group replacement by $\mathrm{Ni}(\mathrm{II})$ ion during coordination with azo dye ligand [34,35].

Mass spectra of mono azo dye ligand and its $\mathrm{Ni}(\mathrm{II})$ complex: The mass spectra of mono azo dye ligand (HMePAI) and $\mathrm{Ni}(\mathrm{II})$ complex and data fragmentation have been studied as stated in the literature $[25,32,34,36]$.

The mass spectrum of the azo dye ligand (Fig. 1, Scheme-II) shows a final peak at $\mathrm{m} / \mathrm{z}^{+}=201.9$ corresponding to the azo dye ligand (HMePAI) $\left[\mathrm{C}_{10} \mathrm{H}_{10} \mathrm{~N}_{4} \mathrm{O}\right]$ (atomic mass 202.22). Other peaks like at $\mathrm{m} / \mathrm{z}^{+}=199.9$ due to loss of $2 \mathrm{H}$ protons, $\left[\mathrm{C}_{10} \mathrm{H}_{8} \mathrm{~N}_{4} \mathrm{O}\right]^{+}$ion while peak at $m / z^{+}=171.1$ corresponding to

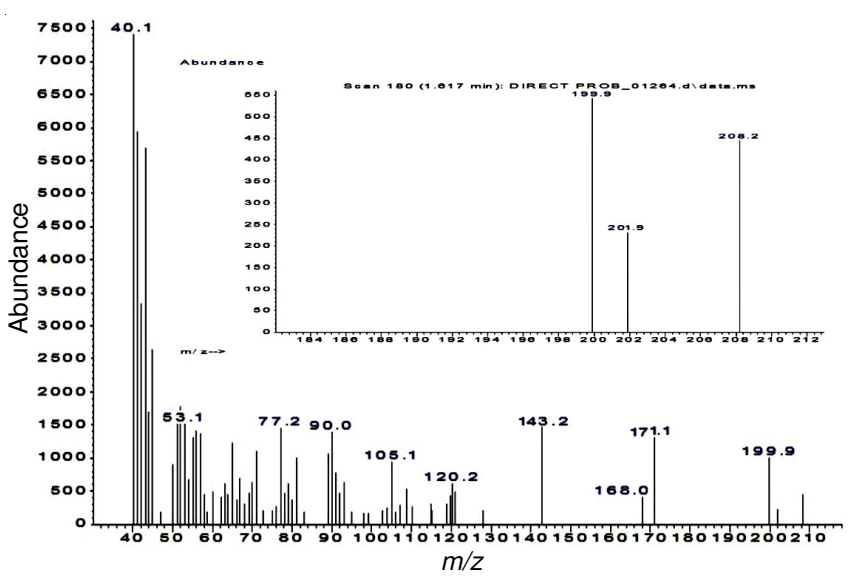

Fig. 1. Mass spectrum of azo dye ligand (HMePAI)

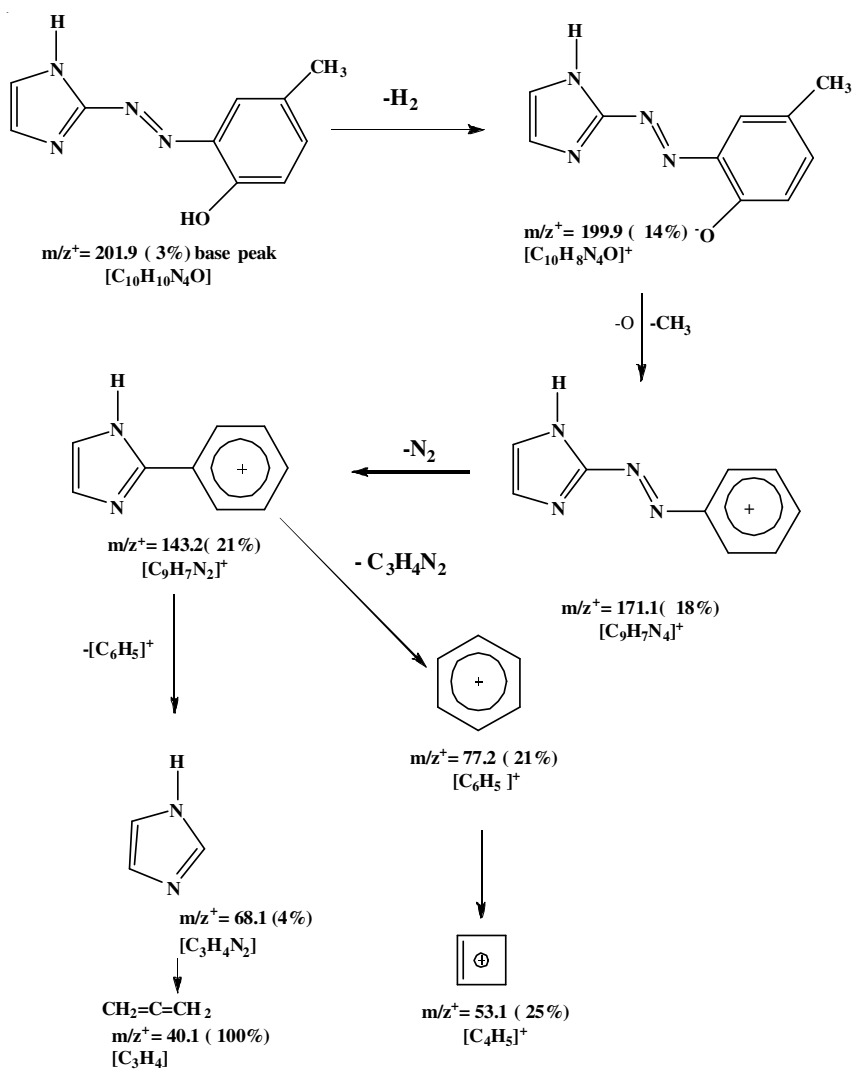

Scheme-II: Mass spectrum fragmentation of mono azo dye ligand (HMePAI)
$\left[\mathrm{C}_{9} \mathrm{H}_{7} \mathrm{~N}_{4}\right]^{+}$ion due to loss methyl group $\left(-\mathrm{CH}_{3}\right)$ and oxygen atom. The loss of azo group (-N=N-) give peak at $m / z^{+}=143.2$ is due to $\left[\mathrm{C}_{9} \mathrm{H}_{7} \mathrm{~N}_{2}\right]^{+}$ion. The peaks at $m / z^{+}=68.1$ and $m / z^{+}=40.1$ due to imidazole ring, $\left[\mathrm{C}_{3} \mathrm{H}_{4} \mathrm{~N}_{2}\right]$ and $\left[\mathrm{C}_{3} \mathrm{H}_{4}\right]$ respectively. Other peaks like $m / z^{+}=77.2$ and 53.1 correspond to $\left[\mathrm{C}_{6} \mathrm{H}_{5}\right]^{+}$and $\left[\mathrm{C}_{4} \mathrm{H}_{5}\right]^{+}$ fragments.

The mass spectrum of the Ni(II) complex (Fig. 2, SchemeIII) showed a molecular ion peak $\mathrm{M}^{+}$at $\mathrm{m} / \mathrm{z}^{+}=461.5$ corresponding to the $\mathrm{Ni}(\mathrm{II})$ complex, $\left[\mathrm{C}_{20} \mathrm{H}_{18} \mathrm{~N}_{8} \mathrm{O}_{2}\right]$, (atomic mass 461.35), equivalent to its molecular weight supporting the suggested structure for the $\mathrm{Ni}$ (II) complex. The $\mathrm{Ni}$ (II) complex gives peak at $m / z^{+}=259.6$ is attributed to $\left[\mathrm{C}_{10} \mathrm{H}_{9} \mathrm{~N}_{4} \mathrm{ONi}\right]^{+}$because of loss $\left[\mathrm{C}_{10} \mathrm{H}_{9} \mathrm{~N}_{4} \mathrm{O}\right]^{+}$. The peak at $\mathrm{m} / \mathrm{z}^{+}=201.1$ corresponding to

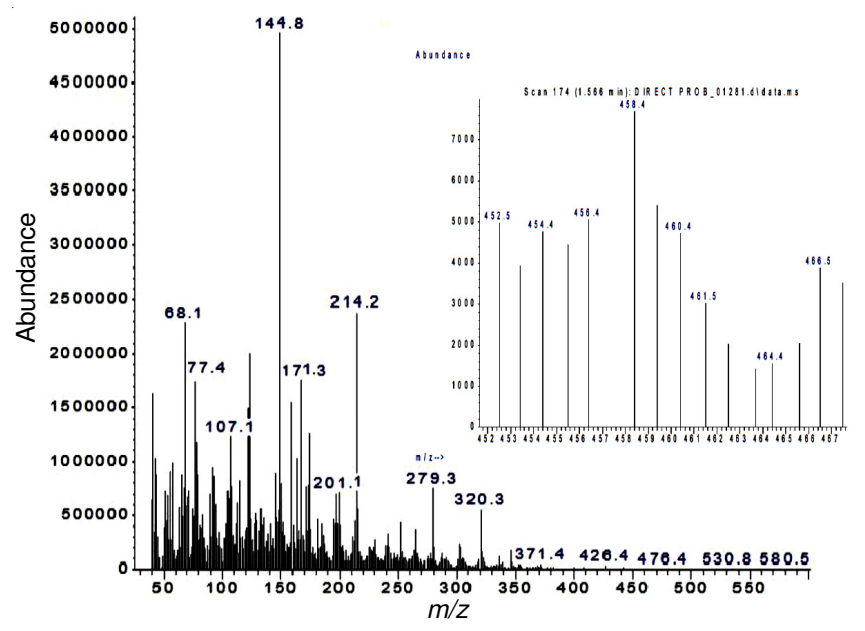

Fig. 2. Mass spectrum of $\mathrm{Ni}(\mathrm{II})$ complex; $\left[\mathrm{Ni}(\mathrm{L})_{2}\right]$

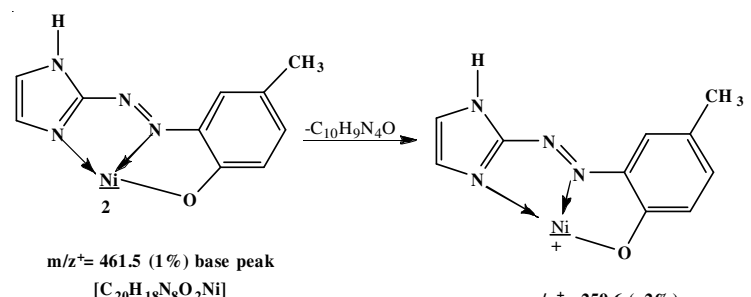
$\left[\mathrm{C}_{20} \mathrm{H}_{18} \mathrm{~N}_{8} \mathrm{O}_{2} \mathrm{Ni}\right]$

$$
\begin{aligned}
& \mathrm{m} / \mathrm{z}^{+}=259.6(2 \% \\
& {\left[\mathrm{C}_{10} \mathrm{H}_{9} \mathrm{~N}_{4} \mathrm{ONi}\right]^{+}}
\end{aligned}
$$


$\mathrm{m} / \mathrm{z}^{+}=144.8(100 \%)$ $\left[\mathrm{C}_{9} \mathrm{H}_{8} \mathrm{~N}_{2}\right]^{+}$

$\mathrm{m} / \mathrm{z}^{+}=77.4(35 \%)$ $\left[\mathrm{C}_{6} \mathrm{H}_{5}\right]^{+}$
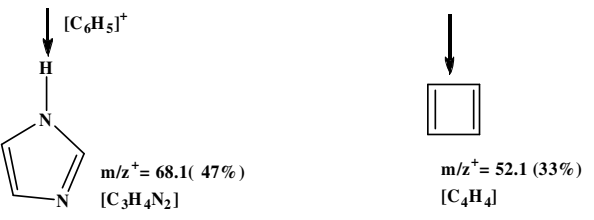

Scheme-III: Mass spectrum fragmentation of Ni complex; $\left[\mathrm{Ni}(\mathrm{L})_{2}\right]$ 
$\left[\mathrm{C}_{10} \mathrm{H}_{9} \mathrm{~N} 4 \mathrm{O}\right]^{+}$ion due to loss nickel ion, while the peak at $\mathrm{m} / \mathrm{z}^{+}$ $=161.1$ due to $\left[\mathrm{C}_{9} \mathrm{H}_{7} \mathrm{~N}_{2} \mathrm{O}\right]^{+}$attributed to loss methyl group $\left(-\mathrm{CH}_{3}\right)$ and azo group $(-\mathrm{N}=\mathrm{N}-)$. Other peaks like $\mathrm{m} / \mathrm{z}^{+}=144.8$, 68.1, 77.4 and 52.1 Correspond to $\left[\mathrm{C}_{9} \mathrm{H}_{8} \mathrm{~N}_{2}\right]^{+}\left[\mathrm{C}_{3} \mathrm{H}_{4} \mathrm{~N}_{2}\right],\left[\mathrm{C}_{6} \mathrm{H}_{5}\right]^{+}$ and $\left[\mathrm{C}_{4} \mathrm{H}_{4}\right]$ respectively. The intensity of these peaks gives the idea of the stability of fragments.

Infrared spectra: Infrared spectral data of the prepared mono azo dye ligand (HMePAI) and its $\mathrm{Cr}(\mathrm{III}), \mathrm{Mn}(\mathrm{II}), \mathrm{Fe}(\mathrm{III})$, $\mathrm{Co}(\mathrm{III}), \mathrm{Ni}(\mathrm{II}), \mathrm{Cu}(\mathrm{II}), \mathrm{Zn}(\mathrm{II}), \mathrm{Cd}(\mathrm{II})$ and $\mathrm{Hg}(\mathrm{II})$ complexes are presented in Table-3. The IR spectrum of the free azo dye ligand showed a weak and broad band around $3420 \mathrm{~cm}^{-1}$ which is assigned to $v(-\mathrm{OH})$ group in the ligand which is absent in all metal complexes showing the deprotonation of the azo dye ligand and coordination with metal ion [24]. The medium band observed at $3181 \mathrm{~cm}^{-1}$ in the free ligand was attributed to $\mathrm{v}(\mathrm{N}-\mathrm{H})$ stretching vibration of the imidazole moiety [37]. The position of this band remained at nearly the same frequency in spectra of the metal complexes, which may be explained by nonparticipation in complex. The weak bands at 3080 and $2961 \mathrm{~cm}^{-1}$ in the spectrum of free ligand which is due to $v(\mathrm{C}-\mathrm{H})$ aromatic and aliphatic respectively. These bands are stable in position as well as intensity in both free ligand and all metal complexes. The strong band at $1645 \mathrm{~cm}^{-1}$ in the free ligand was attributed to $v(\mathrm{C}=\mathrm{N})$ of the imidazole ring $\left(\mathrm{N}_{3}\right)$. This band shifts to lower wave number side $(1542,1605) \mathrm{cm}^{-1}$ in all metal complexes indicating the coordination [24,33]. The sharp band at 1468 $\mathrm{cm}^{-1}$ is characteristic of the azo group $v(-\mathrm{N}=\mathrm{N}-)$ in the free ligand. This band shifted to a lower wave number side in all metal complexes in this frequency to $1458-1450 \mathrm{~cm}^{-1}$ indicates the participation of the azo group nitrogen $\left(\mathrm{N}_{3}\right)$ in coordination with metal ions [34,38].

The far IR spectra of the metal complexes exhibited new band that are not present in the azo dye ligand. These bands are located at (578 and 562) $\mathrm{cm}^{-1}$ and (480 and 432) $\mathrm{cm}^{-1}$ due to $v(\mathrm{M}-\mathrm{O})$ and $v(\mathrm{M}-\mathrm{N})$ respectively $[24,39]$. IR spectral data lead to suggest that the azo dye ligand (HMePAI) behaves as ionic tridentate chelating agent and coordination with metal ion by using sites are the nitrogen atom of the heterocyclic imidazole ring $\left(\mathrm{N}_{3}\right)$, nitrogen atom of azo group nearest to a phenyl ring $\left(\mathrm{N}_{3}\right)$ and a phenolic oxygen to forming two five membered chelating agent.

Electronic spectral studies: The electronic absorption spectra of the azo dye ligand (HMePAI) and its metal complexes were recorded in absolute ethanol $\left(10^{-3} \mathrm{M}\right)$ in the UV-visible region (200-1100) $\mathrm{nm}$ at room temperature. The spectral data and the magnetic moment of prepared metal complexes are presented in Table-4.

The electronic spectrum of free ligand shows three bands at $222 \mathrm{~nm}\left(45045 \mathrm{~cm}^{-1}\right), 247 \mathrm{~nm}\left(40485 \mathrm{~cm}^{-1}\right)$ due to $\pi \rightarrow \pi^{*}$ and $431 \mathrm{~nm}\left(23202 \mathrm{~cm}^{-1}\right)$ may be assigned $\mathrm{n} \rightarrow \pi^{*}$ charge transfer transition due to presence conjugation in the imidazole ring $[33,40]$. The electronic spectrum of the $\mathrm{Cr}(\mathrm{III})$ complex displayed bands at $240 \mathrm{~nm}\left(41667 \mathrm{~cm}^{-1}\right)$ and $480 \mathrm{~nm}\left(20833 \mathrm{~cm}^{-1}\right)$. These two bands are assignable to center ligand and ${ }^{4} \mathrm{~A}_{2} \mathrm{~g} \rightarrow$ ${ }^{4} \mathrm{~T}_{1} \mathrm{~g}_{\text {(F) }}$ transitions respectively in an octahedral environment [24,34].

The Mn(II) complex exhibited three bands, at $250 \mathrm{~nm}$ $\left(40000 \mathrm{~cm}^{-1}\right), 295 \mathrm{~nm}\left(33898 \mathrm{~cm}^{-1}\right)$ and $447 \mathrm{~nm}\left(22371 \mathrm{~cm}^{-1}\right)$ a assignable to center ligand, ${ }^{2} \mathrm{~A}_{1} \mathrm{~g} \rightarrow{ }^{4} \mathrm{~T}_{1} \mathrm{~g}_{(\mathrm{G})}$ and ${ }^{2} \mathrm{~A}_{1} \mathrm{~g} \rightarrow{ }^{4} \mathrm{~T}_{1} \mathrm{~g}_{(\mathrm{P})}$ transitions, respectively in an octahedral environment [24,34,41]. The electronic absorption spectrum of the Fe(III) complex exhibited three absorption bands at $254 \mathrm{~nm}\left(39370 \mathrm{~cm}^{-1}\right), 312$ $\mathrm{nm}\left(32051 \mathrm{~cm}^{-1}\right)$ and $472 \mathrm{~nm}\left(21186 \mathrm{~cm}^{-1}\right)$ due to center ligand, ${ }^{2} \mathrm{~A}_{1} \mathrm{~g} \rightarrow{ }^{2} \mathrm{~T}_{1} \mathrm{~g}_{(\mathrm{G})}$ and ${ }^{2} \mathrm{~A}_{1} \mathrm{~g} \rightarrow{ }^{2} \mathrm{~T}_{1} \mathrm{~g}_{(\mathrm{P})}$ transitions respectively in an octahedral geometry $[28,33,42]$. The electronic spectrum of the Co(III) complex exhibited four absorption bands, the first and second bands at $256 \mathrm{~nm}\left(39063 \mathrm{~cm}^{-1}\right)$ and $297 \mathrm{~nm}(33670$ $\mathrm{cm}^{-1}$ ) which may be attributed to center ligand transitions while the third and four bands located at $505 \mathrm{~nm}\left(19802 \mathrm{~cm}^{-1}\right)$ and $970 \mathrm{~nm}\left(10309 \mathrm{~cm}^{-1}\right)$ assignable to ${ }^{1} \mathrm{~A}_{1} \mathrm{~g} \rightarrow{ }^{1} \mathrm{~T}_{2} \mathrm{~g}_{(\mathrm{F})}$ and ${ }^{1} \mathrm{~A}_{1} \mathrm{~g} \rightarrow{ }^{1} \mathrm{~T}_{1} \mathrm{~g}_{(\mathrm{P})}$ transitions respectively in an octahedral geometry $[34,35,43]$. The Ni(II) complex exhibited three spin-allowed absorption bands at $975 \mathrm{~nm}\left(10256 \mathrm{~cm}^{-1}\right), 635 \mathrm{~nm}\left(15748 \mathrm{~cm}^{-1}\right)$ and $475 \mathrm{~nm}$ $\left(21053 \mathrm{~cm}^{-1}\right)$ which may be attributed to ${ }^{3} \mathrm{~A}_{2} \mathrm{~g} \rightarrow{ }^{3} \mathrm{~T}_{2} \mathrm{~g}_{(\mathrm{F})},{ }^{3} \mathrm{~A}_{2} \mathrm{~g} \rightarrow$ ${ }^{3} \mathrm{~T}_{1} \mathrm{~g}_{(\mathrm{F})}$ and ${ }^{3} \mathrm{~A}_{2} \mathrm{~g} \rightarrow{ }^{3} \mathrm{~T}_{1} \mathrm{~g}_{(\mathrm{P})}$ transitions respectively, while the band at $256 \mathrm{~nm}\left(39062 \mathrm{~cm}^{-1}\right)$ due to center ligand and the shape of this complex in an octahedral geometry [44]. The dark green coloured $\mathrm{Cu}$ (II) complex exhibited a single broad asymmetric band in the region $665 \mathrm{~nm}\left(15038 \mathrm{~cm}^{-1}\right)$. The broadness of the band indicates the three transitions ${ }^{2} \mathrm{~B}_{1} \mathrm{~g} \rightarrow{ }^{2} \mathrm{~A}_{1} \mathrm{~g}_{(\mathrm{u} 1)},{ }^{2} \mathrm{~B}_{1} \mathrm{~g} \rightarrow$ ${ }^{2} \mathrm{~B}_{2} \mathrm{~g}_{(\mathrm{u} 2)}$ and ${ }^{2} \mathrm{~B}_{1} \mathrm{~g} \rightarrow{ }^{2} \mathrm{Eg}$ (u3), which are of similar energy and give rise to only one broad absorption band $\left({ }^{2} \mathrm{~B}_{1} \mathrm{~g} \rightarrow{ }^{2} \mathrm{Eg}\right)$. The broadness of the band may be due to dynamic Jahn-Teller distortion $[7,24,33,34]$. All of these data suggested a distorted octahedral geometry around $\mathrm{Cu}(\mathrm{II})$ complex ion (Z-in or Z-out).

The $\mathrm{Zn}(\mathrm{II}), \mathrm{Cd}(\mathrm{II})$ and $\mathrm{Hg}(\mathrm{II})$ complexes do not show any $d$ - $d$ transition because of saturated with electrons $\left(d^{10}\right)$. The absorption bands at longer wavelength $476 \mathrm{~nm}\left(21008 \mathrm{~cm}^{-1}\right)$,

TABLE-3

INFRARED SPECTRAL DATA $\left(\mathrm{cm}^{-1}\right)$ OF AZO DYE LIGAND AND ITS METAL COMPLEXES (KBr DISC)

\begin{tabular}{lcccccccccc}
\hline \multicolumn{1}{c}{ Group } & HMePAI & $\mathrm{Cr}(\mathrm{III})$ & $\mathrm{Mn}(\mathrm{II})$ & $\mathrm{Fe}(\mathrm{III})$ & $\mathrm{Co}(\mathrm{III})$ & $\mathrm{Ni}(\mathrm{II})$ & $\mathrm{Cu}(\mathrm{II})$ & $\mathrm{Zn}(\mathrm{II})$ & $\mathrm{Cd}(\mathrm{II})$ & $\mathrm{Hg}(\mathrm{II})$ \\
\hline$v(\mathrm{OH})$ & $3420 \mathrm{w}, \mathrm{br}$ & - & - & - & - & - & - & - & - & - \\
$v(\mathrm{~N}-\mathrm{H})$ & $3181 \mathrm{~m}$ & $3282 \mathrm{~s}$ & $3278 \mathrm{~m}$ & $3363 \mathrm{~m}, \mathrm{br}$ & $3341 \mathrm{~m}, \mathrm{br}$ & $3356 \mathrm{~m}, \mathrm{br}$ & $3340 \mathrm{~s}$ & $3340 \mathrm{w}, \mathrm{br}$ & $3348 \mathrm{~m}, \mathrm{br}$ & $3248 \mathrm{~m}$ \\
$v(\mathrm{C}=\mathrm{N})$ Imd. & $1645 \mathrm{vs}$ & $1565 \mathrm{~m}$ & $1542 \mathrm{~m}$ & $1604 \mathrm{w}$ & $1605 \mathrm{w}$ & $1542 \mathrm{w}$ & $1604 \mathrm{w}$ & $1602 \mathrm{w}$ & $1601 \mathrm{w}$ & $1568 \mathrm{w}$ \\
$v(\mathrm{C}=\mathrm{C})$ & $1542 \mathrm{vs}$ & $1510 \mathrm{~s}$ & $1512 \mathrm{~s}$ & $1518 \mathrm{~s}$ & $1504 \mathrm{~s}$ & $1515 \mathrm{~s}$ & $1515 \mathrm{~s}$ & $1518 \mathrm{~s}$ & $1515 \mathrm{~s}$ & $1518 \mathrm{~m}$ \\
$v(\mathrm{~N}=\mathrm{N})$ & $1480 \mathrm{~m}$ & $1450 \mathrm{~m}$ & $1458 \mathrm{w}$ & $1458 \mathrm{w}$ & $1458 \mathrm{w}$ & $1458 \mathrm{w}$ & $1454 \mathrm{w}$ & $1450 \mathrm{w}$ & $1450 \mathrm{w}$ & $1458 \mathrm{w}$ \\
$v(\mathrm{C}-\mathrm{N}=\mathrm{N}-\mathrm{C})$ & $1278 \mathrm{w}$, & $1245 \mathrm{~m}$, & $1281 \mathrm{w}$, & $1250 \mathrm{w}$, & $1249 \mathrm{w}$, & $1234 \mathrm{w}$, & $1250 \mathrm{w}$, & $1249 \mathrm{w}$, & $1249 \mathrm{w}$, & $1249 \mathrm{w}$, \\
& $750 \mathrm{~m}$ & $663 \mathrm{w}$ & $633 \mathrm{~m}$ & $638 \mathrm{w}$ & $671 \mathrm{w}$ & $671 \mathrm{~s}$ & $670 \mathrm{w}$ & $675 \mathrm{w}$ & $663 \mathrm{w}$ & $671 \mathrm{w}$ \\
$v($ Benz. R. Deff. $)$ & $1110 \mathrm{~m}$ & $1110 \mathrm{w}$ & $1118 \mathrm{w}$ & $1134 \mathrm{w}$ & $1110 \mathrm{w}$ & $1111 \mathrm{w}$ & $1134 \mathrm{~m}$ & $1118 \mathrm{w}$ & $1119 \mathrm{w}$ & $1110 \mathrm{w}$ \\
$v($ Imi- R. Deff. $)$ & $810 \mathrm{~m}$ & $810 \mathrm{~s}$ & $818 \mathrm{~s}$ & $817 \mathrm{~s}$ & $818 \mathrm{~s}$ & $818 \mathrm{~s}$ & $818 \mathrm{~s}$ & $817 \mathrm{~m}$ & $818 \mathrm{~s}$ & $810 \mathrm{~s}$ \\
$v(\mathrm{M}-\mathrm{O})$ & - & $570 \mathrm{w}$ & $571 \mathrm{w}$ & $563 \mathrm{w}$ & $562 \mathrm{w}$ & $573 \mathrm{w}$ & $572 \mathrm{w}$ & $572 \mathrm{w}$ & $578 \mathrm{w}$ & $571 \mathrm{w}$ \\
$v(\mathrm{M}-\mathrm{N})$ & - & $465 \mathrm{w}$ & $455 \mathrm{w}$ & $432 \mathrm{w}$ & $462 \mathrm{w}$ & $465 \mathrm{w}$ & $480 \mathrm{w}$ & $464 \mathrm{w}$ & $438 \mathrm{w}$ & $472 \mathrm{w}$ \\
\hline
\end{tabular}




\begin{tabular}{|c|c|c|c|c|c|c|}
\hline \multicolumn{7}{|c|}{$\begin{array}{c}\text { TABLE-4 } \\
\text { ELECTRONIC SPECTRA }\left(\mathrm{nm}, \mathrm{cm}^{-1}\right) \text {, MAGNETIC MOMENTS, PROPOSED } \\
\text { STRUCTURE AND HYBRIDIZATION OF METAL COMPLEXES }\end{array}$} \\
\hline Compounds & $\lambda_{\max }(\mathrm{nm})$ & $\begin{array}{l}\text { Absorption } \\
\text { bands }\left(\mathrm{cm}^{-1}\right)\end{array}$ & Transitions & $\mu_{\text {eff }}(\mathrm{BM})$ & Geometry & Hybridization \\
\hline \multirow{3}{*}{$\begin{array}{l}\text { Ligand }=\mathrm{HL} \\
(\mathrm{HMePAI})\end{array}$} & 222 & 45045 & $\pi \rightarrow \pi *$ & \multirow{3}{*}{-} & \multirow{3}{*}{-} & \multirow{3}{*}{-} \\
\hline & 247 & 40485 & $\pi \rightarrow \pi *$ & & & \\
\hline & 431 & 23202 & $\mathrm{n} \rightarrow \pi *$ & & & \\
\hline \multirow[b]{2}{*}[\mathrm{Cr}(\mathrm{L})_{2}]{$\mathrm{Cl}$} & 240 & 41667 & Center ligand & \multirow[b]{2}{*}{3.61} & \multirow[b]{2}{*}{ Octahedral (Regular) } & \multirow{2}{*}{$d^{2} s p^{3}$} \\
\hline & 480 & 20833 & ${ }^{4} \mathrm{~A}_{2} \mathrm{~g} \rightarrow{ }^{4} \mathrm{~T}_{1} \mathrm{~g}_{(\mathrm{F})}$ & & & \\
\hline \multirow{3}{*}[\mathrm{Mn}(\mathrm{L})_{2}]{} & 250 & 40000 & Center ligand & \multirow{3}{*}{1.81} & \multirow{3}{*}{ Octahedral (Distorted) (Z-out) } & \multirow{3}{*}{$\begin{array}{c}d^{2} s p^{3} \\
\text { (Low spin) }\end{array}$} \\
\hline & 295 & 33898 & ${ }^{2} \mathrm{~A}_{1} \mathrm{~g} \rightarrow{ }^{4} \mathrm{~T}_{1} \mathrm{~g}_{(\mathrm{G})}$ & & & \\
\hline & 447 & 22371 & ${ }^{2} \mathrm{~A}_{1} \mathrm{~g} \rightarrow{ }^{4} \mathrm{~T}_{1} \mathrm{~g}_{(\mathrm{P})}$ & & & \\
\hline \multirow{3}{*}[\mathrm{Fe}(\mathrm{L})_{2}]{$\mathrm{Cl}$} & 254 & 39370 & Center ligand & \multirow{3}{*}{1.78} & \multirow{3}{*}{ Octahedral (Distorted) (Z-out) } & \multirow{3}{*}{$\begin{array}{c}d^{2} s p^{3} \\
\text { (Low spin) }\end{array}$} \\
\hline & 312 & 32051 & ${ }^{2} \mathrm{~A}_{1} \mathrm{~g} \rightarrow{ }^{2} \mathrm{~T}_{1} \mathrm{~g}_{(\mathrm{G})}$ & & & \\
\hline & 472 & 21186 & ${ }^{2} \mathrm{~A}_{1} \mathrm{~g} \rightarrow{ }^{2} \mathrm{~T}_{1} \mathrm{~g}_{(\mathrm{P})}$ & & & \\
\hline \multirow{4}{*}[\mathrm{Co}(\mathrm{L})_{2}]{$\mathrm{Cl}$} & 256 & 39063 & Center ligand & \multirow{4}{*}{ Diamag. } & \multirow{4}{*}{ Octahedral (Regular) } & \multirow{4}{*}{$\begin{array}{c}d^{2} s p^{3} \\
\text { (Low spin) }\end{array}$} \\
\hline & 297 & 33670 & Center ligand & & & \\
\hline & 505 & 19802 & ${ }^{1} \mathrm{~A}_{1} \mathrm{~g} \rightarrow{ }^{1} \mathrm{~T}_{2} \mathrm{~g}_{(\mathrm{F})}$ & & & \\
\hline & 970 & 10309 & ${ }^{1} \mathrm{~A}_{1} \mathrm{~g} \rightarrow{ }^{1} \mathrm{~T}_{1} \mathrm{~g}_{(\mathrm{F})}$ & & & \\
\hline \multirow{3}{*}[\mathrm{Ni}(\mathrm{L})_{2}]{} & 475 & 21053 & ${ }^{3} \mathrm{~A}_{2} \mathrm{~g} \rightarrow{ }^{3} \mathrm{~T}_{1} \mathrm{~g}_{(\mathrm{P})}$ & \multirow{3}{*}{3.08} & \multirow{3}{*}{ Octahedral (Regular) } & \multirow{3}{*}{$\begin{array}{c}s p^{3} d^{2} \\
\text { (High spin) }\end{array}$} \\
\hline & 635 & 15748 & ${ }^{3} \mathrm{~A}_{2} \mathrm{~g} \rightarrow{ }^{3} \mathrm{~T}_{1} \mathrm{~g}_{(\mathrm{F})}$ & & & \\
\hline & 975 & 10256 & ${ }^{3} \mathrm{~A}_{2} \mathrm{~g} \rightarrow{ }^{3} \mathrm{~T}_{2} \mathrm{~g}_{(\mathrm{F})}$ & & & \\
\hline$\left[\mathrm{Cu}(\mathrm{L})_{2}\right]$ & 665 & 15038 & ${ }^{2} \mathrm{~B}_{1} \mathrm{~g} \rightarrow{ }^{2} \mathrm{Eg}$ & 1.78 & Octahedral (distorted) (Z-in or Z-out) & $s p^{3} d^{2}$ \\
\hline$\left[\mathrm{Zn}(\mathrm{L})_{2}\right]$ & 476 & 21008 & $\mathrm{~d} \pi(\mathrm{Zn})^{+2} \rightarrow \pi *(\mathrm{~L})$ & Diamag. & Octahedral (Regular) & $s p^{3} d^{2}$ \\
\hline$\left[\mathrm{Cd}(\mathrm{L})_{2}\right]$ & 452 & 22124 & $\mathrm{~d} \pi(\mathrm{Cd})^{+2} \rightarrow \pi *(\mathrm{~L})$ & Diamag. & Octahedral (Regular) & $s p^{3} d^{2}$ \\
\hline$\left[\mathrm{Hg}(\mathrm{L})_{2}\right]$ & 479 & 20877 & $\mathrm{~d} \pi(\mathrm{Hg})^{+2} \rightarrow \pi *(\mathrm{~L})$ & Diamag. & Octahedral (Regular) & $s p^{3} d^{2}$ \\
\hline
\end{tabular}

$452 \mathrm{~nm}\left(22124 \mathrm{~cm}^{-1}\right)$ and $479 \mathrm{~nm}\left(20877 \mathrm{~cm}^{-1}\right)$ assignable to $\mathrm{M} \rightarrow \pi^{*}$ (ligand) charge transfer transitions and in an octahedral environment $[27,29,45]$. The UV-visible spectra of azo dye ligand (HMePAI) and some metal complexes are shown in Fig. 3.

Magnetic studies: The magnetic moment value of $\mathrm{Cr}$ (III) complex is $3.61 \mathrm{BM}$, this value is too close to the theoretical magnetic moment for the $\mathrm{Cr}(\mathrm{III})$ ion $\left(\mu_{\mathrm{eff}}=3.87 \mathrm{BM}\right)$ due to presence of three electrons unpaired $\left(\mathrm{t}_{2} \mathrm{~g}^{3} \mathrm{eg}^{0}\right)$, which may suggest a regular structure and $d^{2} s p^{3}$ hybridization [24,46]. The Mn(II) complex exhibited the magnetic moment value of 1.81 BM which indicates distorted octahedral geometry (Z-out) due to presence of one electron unpaired $\left(\mathrm{t}_{2} \mathrm{~g}^{5} \mathrm{eg}^{0}\right.$, low spin) because of strong ligand and $d^{2} s p^{3}$ hybridization [24,28,33]. The magnetic moment value of the Fe(III) complex is 1.78 $\mathrm{BM}$ due to presence of one electron unpaired $\left(\mathrm{t}_{2} \mathrm{~g}^{5} \mathrm{eg}^{0}\right)$ which may suggest distorted octahedral geometry (Z-out, low spin) and $d^{2} s p^{3}$ hybridization $[28,33,47]$. The Co(II) complex was found to be diamagnetic indicates the low spin behaviour because of that $\mathrm{Co}$ (II) ion which is oxidized to $\mathrm{Co}$ (III) ion during complexation in aqueous solution with presence of strong ligand such as azo imidazole ligands which may suggest a regular geometry $\left(\mathrm{t}_{2} \mathrm{~g}^{6} \mathrm{eg}^{0}\right)$ and $d^{2} s p^{3}$ hybridization $[48,49]$. The magnetic moment value of the Ni(II)complex is $3.08 \mathrm{BM}$ within the range of 2.8-3.5 BM because of two electrons unpaired which may suggest a regular octahedral structure $\left(\mathrm{t}_{2} \mathrm{~g}^{6}\right.$ $\mathrm{eg}^{2}$, high spin) and $s p^{3} d^{2}$ hybridization [44,50]. The $\mathrm{Cu}(\mathrm{II})$ complex showed magnetic moment of (1.78) BM is slightly higher than the spin-only value of (1.73) BM expected for one electron unpaired which offers the possibility of an distorted octahedral geometry, $\left(\mathrm{t}_{2} \mathrm{~g}^{6} \mathrm{eg}^{3}\right)$ and $s p^{3} d^{2}$ hybridization for these metal complexes $[32,35,51]$. The magnetic moment values of
$\mathrm{Zn}$ (II), $\mathrm{Cd}(\mathrm{II})$ and $\mathrm{Hg}$ (II) complexes are diamagnetic consistent with the $d^{10}\left(\mathrm{t}_{2} \mathrm{~g}^{6} \mathrm{eg}^{4}\right)$ configuration which indicates an octahedral geometry and $s p^{3} d^{2}$ hybridization [52,53].

According to these results, the structural formula of prepared metal complexes in this work may be proposed in Fig. 4.

Thermal studies: The ligand and its metal complexes have thermal properties are examined from ambient temperature up to $700{ }^{\circ} \mathrm{C}$ in nitrogen atmosphere $[54,55]$. The results of thermogravimetry of ligand and metals complexes are listed in Table-5.

X-ray diffraction study (XRD): In this work, we studied the crystalline structure of prepared ligand (HMePAI) and its metal complexes in solid state by using X-rays diffractometer in the range of $2 \theta=0-80^{\circ}$ value. It is observed that ligand contained several sharp peaks which indicate the crystalline nature, while the metal complexes were different in nature where observed the $\mathrm{Cr}$ (III), $\mathrm{Fe}$ (III) and Cd(II) metal complexes contained rate the crystalline nature more than the amorphous nature because the sharp peaks are more than broad peaks while observed in $\mathrm{Mn}$ (II), $\mathrm{Cu}$ (II) and $\mathrm{Zn}$ (II) metal complexes contained rate the crystalline nature nearly equal the amorphous nature because the sharp peaks nearly equal broad peaks while observed in the $\mathrm{Co}$ (III), $\mathrm{Ni}$ (II) and $\mathrm{Hg}$ (II) metal complexes contained rate the crystalline nature less than the amorphous nature because the sharp peaks are less than broad peaks [56,57]. To calculate d-spacing or d values of reflections were obtained using Braggs equation $\mathrm{n} \lambda=2 \mathrm{~d} \sin \theta$, where $\mathrm{d}$ is the spacing between the crystalline levels, $\mathrm{n}$ is an integer $(1,2,3 \ldots), \lambda$ is the wavelength of $\mathrm{X}$-ray $\mathrm{CuK}_{\alpha}=1.540598 \AA$, $\theta$ is the diffraction angle and the values of $\mathrm{d}$ and associated data depict the $2 \theta$ value of each peak, relative intensity also the particle size distribution histogram for ligand and metal complexes are listed 

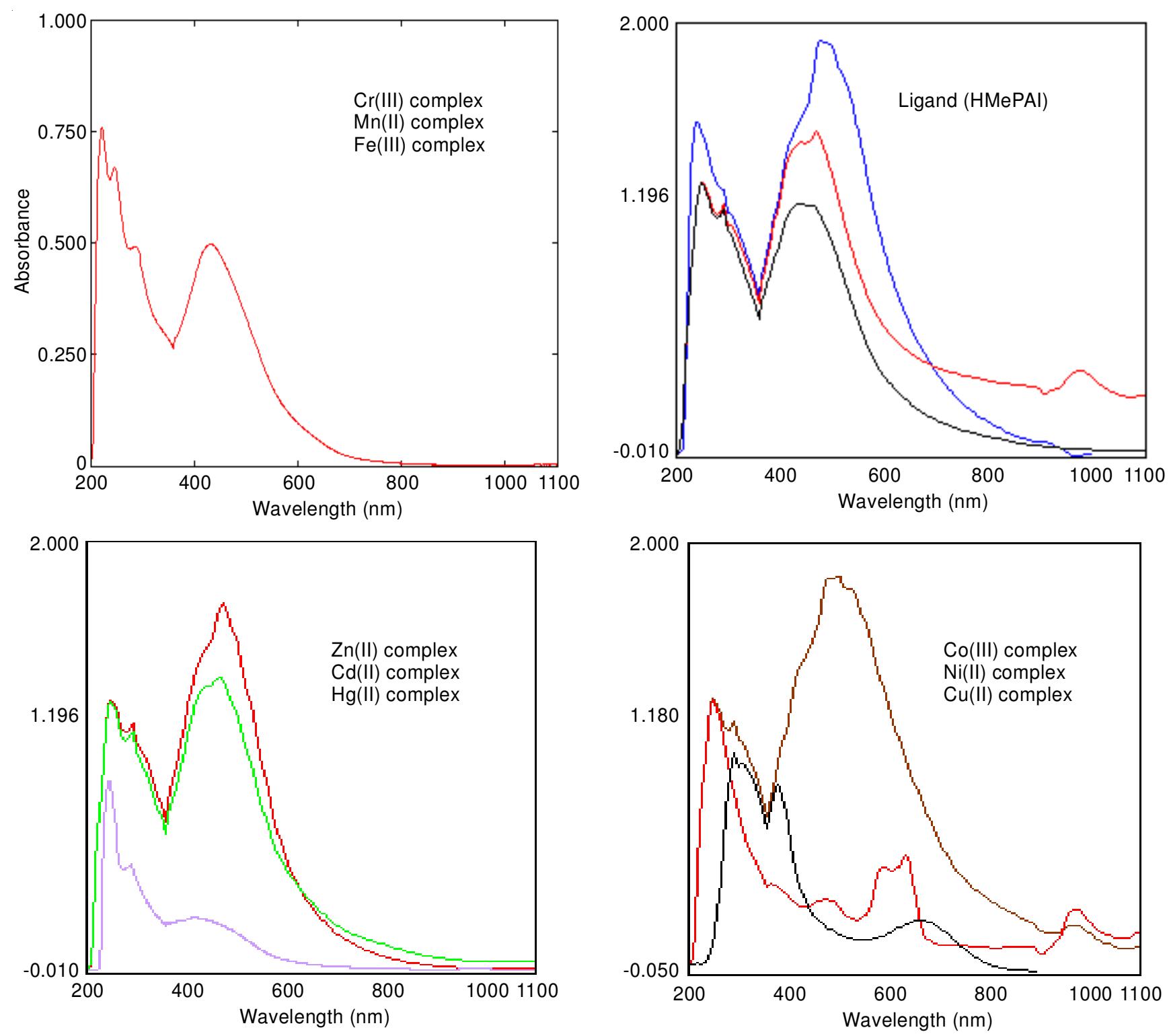

Fig. 3. UV-visible spectra of azo dye ligand (HMePAI) and its metal complexes
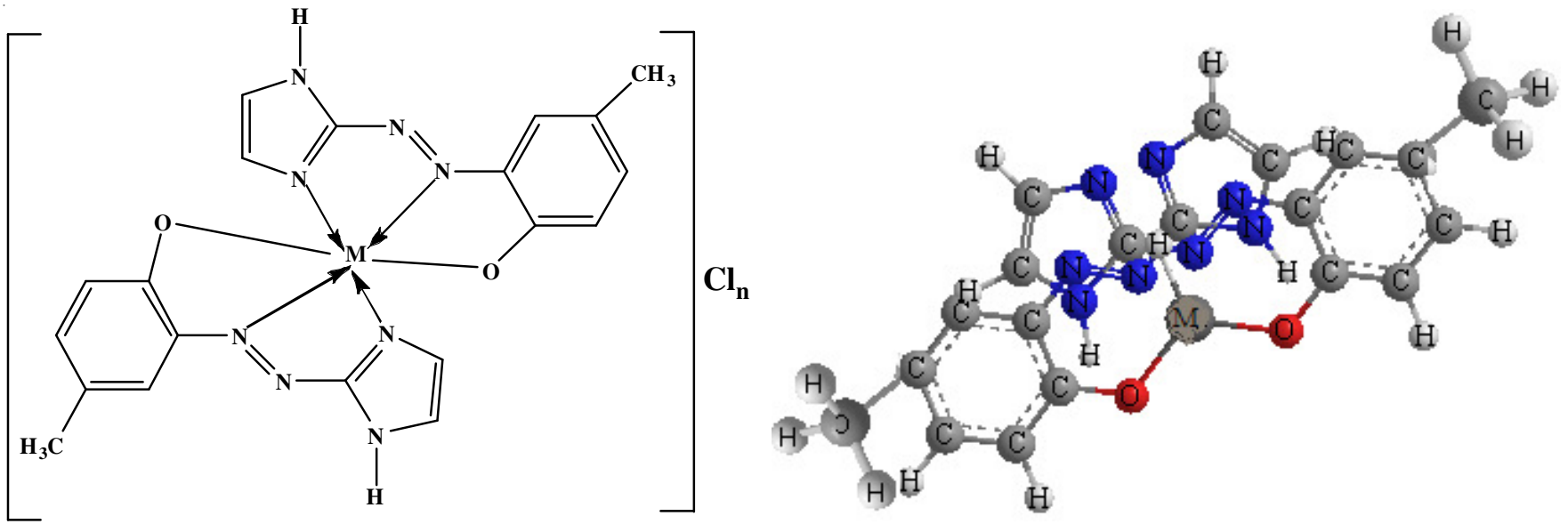

$\mathrm{M}=\mathrm{Cr}(\mathrm{III}), \mathrm{Fe}(\mathrm{III})$ and $\mathrm{Co}(\mathrm{III}) ; \mathrm{n}=1$

$\mathrm{M}=\mathrm{Mn}(\mathrm{II}), \mathrm{Ni}(\mathrm{II}), \mathrm{Cu}(\mathrm{II}), \mathrm{Zn}(\mathrm{II}), \mathrm{Cd}(\mathrm{II})$ and $\mathrm{Hg}(\mathrm{II}) ; \mathrm{n}=0$

Fig. 4. Proposed structural formula of chelate metal complexes

in Table-6. The XRD peak shift to lower angle in metal complexes because of increased of $d$-spacing in the complexes and the average size of the particles and their size distribution were evaluated by the Scherer equation, $D=k \lambda / \beta \cos \theta$, where $D$ is the average grain size, $\mathrm{k}$ is Blanks constant $(0.891), \lambda$ is the $X$-ray wavelength $(0.15405 \mathrm{~nm})$ and $\theta$ and $\beta$ are the diffraction 
Vol. 30, No. 2 (2018) Synthesis and Biological Studies of Some Metal Complexes Derived from Heterocyclic Mono Azo Dye Ligand 287

\begin{tabular}{|c|c|c|c|c|c|c|}
\hline & THERMAL A & ALYSIS OF A & $\begin{array}{r}\text { TABL } \\
\text { DYE LIGAND }\end{array}$ & $\begin{array}{l}-5 \\
\text { (HMePAI) AND ITS METAL C }\end{array}$ & & \\
\hline Compound & TG range $\left({ }^{\circ} \mathrm{C}\right)$ & DTG $_{\text {Max }}\left({ }^{\circ} \mathrm{C}\right)$ & Mass loss (\%) & Assignment & Residue & $\operatorname{DSC}\left({ }^{\circ} \mathrm{C}\right)$ \\
\hline & $25-116$ & 286 & 1.75 & Evolution of $\mathrm{Co}_{2}$ and moisture & & \\
\hline & $116-297$ & 450 & 15.79 & Loss $\mathrm{CH}_{3}$ group & & \\
\hline$(\mathrm{HMePAI})=\mathrm{HL}$ & $297-431$ & 521 & 31.58 & Loss $\mathrm{OH}$ group & 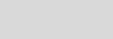 & $451(+)$ \\
\hline $\mathrm{C}_{10} \mathrm{H}_{10} \mathrm{~N}_{4} \mathrm{O}$ & $431-512$ & & 57.35 & Loss azo group and & - & $532(+)$ \\
\hline & $512 ' 586$ & & 88.60 & Loss imidazole ring & & \\
\hline & $35-159$ & 210 & 2.96 & $\begin{array}{l}\text { A part of the ligand } \\
\text { Evolution of } \mathrm{CO}_{2} \text { and moisture }\end{array}$ & & \\
\hline & $159-233$ & 481 & 15.65 & Loss $\mathrm{CH}_{3}$ group & & \\
\hline$\left[\mathrm{Cr}\left(\mathrm{C}_{10} \mathrm{H}_{9} \mathrm{~N}_{4} \mathrm{O}\right)_{2}\right] . \mathrm{Cl}$ & $233-442$ & 539 & 31.08 & Loss azo group & $\mathrm{Cr}$ & $507(+)$ \\
\hline & $442 ' 576$ & & 89.77 & $\begin{array}{l}\text { Loss imidazole ring and } \\
\text { Loss of a part of the ligand }\end{array}$ & & \\
\hline & $34-160$ & 493 & 3.33 & Evolution of $\mathrm{Co}_{2}$ and moisture & & \\
\hline & $160-312$ & 532 & 21.29 & Loss $\mathrm{CH}_{3}$ group & & \\
\hline$\left[\mathrm{Mn}\left(\mathrm{C}_{10} \mathrm{H}_{9} \mathrm{~N}_{4} \mathrm{O}\right)_{2}\right]$ & $312^{\prime} 465$ & & 33.90 & Loss azo group & $\mathrm{Mn}$ & $497(+)$ \\
\hline & $465-568$ & & 83.00 & $\begin{array}{l}\text { Loss imidazole ring and } \\
\text { Loss of a part of the ligand }\end{array}$ & & \\
\hline & $36-131$ & 202 & 2.35 & Evolution of $\mathrm{CO}_{2}$ and moisture & & \\
\hline & $131-224$ & 363 & 51.08 & Loss $\mathrm{CH}_{3}$ group & & \\
\hline$\left[\mathrm{Fe}\left(\mathrm{C}_{10} \mathrm{H}_{9} \mathrm{~N}_{4} \mathrm{O}\right)_{2}\right] \cdot \mathrm{Cl}$ & 224-338 & 450 & 28.75 & Loss azo group & $\mathrm{Fe}$ & $371(+)$ \\
\hline & $338-494$ & & 83.61 & $\begin{array}{l}\text { Loss imidazole ring and } \\
\text { Loss of a part of the ligand }\end{array}$ & & \\
\hline & $38-153$ & 37 & 2.36 & Evolution of $\mathrm{Co}_{2}$ and moisture & & $252(-)$ \\
\hline & $153-231$ & 252 & 15.69 & Loss $\mathrm{CH}_{3}$ group & & $512(+)$ \\
\hline$\left[\mathrm{Co}\left(\mathrm{C}_{10} \mathrm{H}_{9} \mathrm{~N}_{4} \mathrm{O}\right)_{2}\right] \cdot \mathrm{Cl}$ & $231-448$ & 536 & 34.21 & Loss azo group & Co & $535(+)$ \\
\hline & $448-596$ & 579 & 81.95 & $\begin{array}{l}\text { Loss imidazole ring and } \\
\text { Loss of a part of the ligand }\end{array}$ & & $577(+)$ \\
\hline & $33-160$ & 492 & 2.98 & Evolution of $\mathrm{Co}_{2}$ and moisture & & \\
\hline & $160-235$ & 591 & 15.64 & Loss $\mathrm{CH}_{3}$ group & & \\
\hline$\left[\mathrm{Ni}\left(\mathrm{C}_{10} \mathrm{H}_{9} \mathrm{~N}_{4} \mathrm{O}\right)_{2}\right]$ & $235-441$ & & 31.00 & Loss azo group & $\mathrm{Ni}$ & $493(+)$ \\
\hline & $441-578$ & & 89.78 & $\begin{array}{l}\text { Loss imidazole ring and } \\
\text { Loss of a part of the ligand }\end{array}$ & & \\
\hline & $36-163$ & 217 & 3.32 & Evolution of $\mathrm{Co}_{2}$ and moisture & & \\
\hline & $163-315$ & 309 & 21.31 & Loss $\mathrm{CH}_{3}$ group & & $312(+)$ \\
\hline$\left[\mathrm{Cu}\left(\mathrm{C}_{10} \mathrm{H}_{9} \mathrm{~N}_{4} \mathrm{O}\right)_{2}\right]$ & $315-463$ & 502 & 34.02 & Loss azo group & $\mathrm{Cu}$ & $508(+)$ \\
\hline & $463-567$ & & 82.85 & Loss imidazole ring and & & \\
\hline & $37-133$ & & & Loss of a part of the ligand & & \\
\hline & $37-133$ & 193 & 2.34 & Evolution of $\mathrm{Co}_{2}$ and moisture & & \\
\hline & $133-226$ & 387 & 15.06 & Loss $\mathrm{CH}_{3}$ group & & \\
\hline$\left[\mathrm{Zn}\left(\mathrm{C}_{10} \mathrm{H}_{9} \mathrm{~N}_{4} \mathrm{O}\right)_{2}\right]$ & $226-339$ & 462 & 28.73 & Loss azo group & $\mathrm{Zn}$ & $386(+)$ \\
\hline & $339-493$ & 469 & 83.63 & $\begin{array}{l}\text { Loss imidazole ring and } \\
\text { Loss of a part of the ligand }\end{array}$ & & \\
\hline & $36-155$ & 213 & 2.33 & Evolution of $\mathrm{Co}_{2}$ and moisture & & \\
\hline & $155-229$ & 421 & 15.73 & Loss $\mathrm{CH}_{3}$ group & & $422(+)$ \\
\hline$\left[\mathrm{Cd}\left(\mathrm{C}_{10} \mathrm{H}_{9} \mathrm{~N}_{4} \mathrm{O}\right)_{2}\right]$ & $229-446$ & 534 & 34.18 & Loss azo group & $\mathrm{Cd}$ & $545(+)$ \\
\hline & 446-598 & & 82.01 & Loss imidazole ring and & & \\
\hline & $36-161$ & 467 & 2.95 & Evolution of $\mathrm{CO}_{2}$ and moisture & & \\
\hline & $161-231$ & 533 & 15.67 & Loss $\mathrm{CH}_{3}$ group & & \\
\hline$\left[\mathrm{Hg}\left(\mathrm{C}_{10} \mathrm{H}_{9} \mathrm{~N}_{4} \mathrm{O}\right)_{2}\right]$ & $231-444$ & 619 & 31.06 & Loss azo group & $\mathrm{Hg}$ & $470(+)$ \\
\hline & $444-574$ & & 89.76 & $\begin{array}{l}\text { Loss imidazole ring and } \\
\text { Loss of a part of the ligand }\end{array}$ & & $53 /(+)$ \\
\hline
\end{tabular}

TABLE-6

INTER PLANAR DISTANCES AND THE $2 \theta$ VALUE OF EACH PEAK, RELATIVE INTENSITY, CRYSTALLOGRAPHIC DATA AND FWHM FOR LIGAND (HMePAI) AND METAL COMPLEXES

\begin{tabular}{|c|c|c|c|c|c|c|c|}
\hline Compound & $2 \theta_{\text {obs }}\left({ }^{\circ}\right)$ & $\begin{array}{c}\mathrm{d}_{\mathrm{obs}} \text { spacing } \\
(\AA)\end{array}$ & $\begin{array}{l}\text { Intensity } \\
\left(\mathrm{I} / \mathrm{I}_{\mathrm{o}}\right)(\%) \\
\end{array}$ & Pos. $\left[2 \theta,{ }^{\circ}\right]$ & FWHM $\left[2 \theta,{ }^{\circ}\right]$ & $\begin{array}{l}\text { Crystallite size } \\
(\mathrm{D}, \mathrm{nm})\end{array}$ & Lattice strain \\
\hline \multirow{8}{*}{$\mathrm{HL}=\mathrm{HMePAI}$} & 27.5 & 3.2413 & 19 & 27.5869 & 0.1771 & 48.26 & 0.0031 \\
\hline & 32.0 & 2.7946 & 100 & 31.8806 & 0.2362 & 36.55 & 0.0036 \\
\hline & 45.5 & 1.9919 & 40 & 45.6412 & 0.1771 & 50.85 & 0.0018 \\
\hline & 54.0 & 1.6967 & 6 & 54.0206 & 0.2362 & 39.44 & 0.0020 \\
\hline & 56.5 & 1.6274 & 15 & 56.6248 & 0.2362 & 39.92 & 0.0019 \\
\hline & 66.5 & 1.4049 & 12 & 66.3400 & 0.3542 & 27.99 & 0.0024 \\
\hline & 73.25 & 1.2912 & 2 & 73.1937 & 0.1771 & 58.37 & 0.0010 \\
\hline & 75.5 & 1.2582 & 14 & 75.3998 & 0.2880 & 36.42 & 0.0016 \\
\hline
\end{tabular}




\begin{tabular}{|c|c|c|c|c|c|c|c|}
\hline \multirow{7}{*}[\mathrm{Cr}(\mathrm{C}_{10}\mathrm{H}_{9}\mathrm{N}_{4}\mathrm{O})_{2}]{$\cdot \mathrm{Cl}$} & 21.25 & 4.1778 & 31 & 27.4319 & 0.3542 & 24.12 & 0.0063 \\
\hline & 28.0 & 3.1841 & 31 & 31.7620 & 0.2362 & 36.54 & 0.0036 \\
\hline & 32.0 & 2.7946 & 100 & 45.5145 & 0.1771 & 50.83 & 0.0018 \\
\hline & 45.5 & 1.9919 & 38 & 56.5346 & 0.2362 & 39.9 & 0.0019 \\
\hline & 56.5 & 1.6274 & 17 & 66.2849 & 0.3542 & 27.99 & 0.0024 \\
\hline & 66.5 & 1.4049 & 8 & 75.3267 & 0.3600 & 29.12 & 0.0020 \\
\hline & 75.5 & 1.2582 & 11 & & & & \\
\hline \multirow{7}{*}[\mathrm{Mn}(\mathrm{C}_{10}\mathrm{H}_{9}\mathrm{N}_{4}\mathrm{O})_{2}]{} & 23.5 & 3.7826 & 65 & 31.8420 & 0.1771 & 48.74 & 0.0027 \\
\hline & 32.0 & 2.7946 & 100 & 45.5842 & 0.2362 & 38.12 & 0.0025 \\
\hline & 46.0 & 1.9714 & 56 & 56.5969 & 0.2952 & 31.93 & 0.0024 \\
\hline & 57.0 & 1.6143 & 31 & 75.4764 & 0.4320 & 24.29 & 0.0024 \\
\hline & 59.5 & 1.5523 & 21 & & & & \\
\hline & 66.5 & 1.4049 & 21 & & & & \\
\hline & 75.5 & 1.2582 & 23 & & & & \\
\hline \multirow{14}{*}[\mathrm{Fe}(\mathrm{C}_{10}\mathrm{H}_{9}\mathrm{N}_{4}\mathrm{O})_{2}]{$\cdot \mathrm{Cl}$} & 21.5 & 4.1298 & 29 & 23.0329 & 0.1771 & 47.84 & 0.0038 \\
\hline & 23.0 & 3.8637 & 34 & 27.4571 & 0.1771 & 48.25 & 0.0032 \\
\hline & 27.5 & 3.2408 & 28 & 31.8039 & 0.2362 & 36.54 & 0.0036 \\
\hline & 31.75 & 2.8160 & 100 & 32.7477 & 0.1771 & 48.85 & 0.0026 \\
\hline & 32.75 & 2.7323 & 55 & 45.5547 & 0.2362 & 38.11 & 0.0025 \\
\hline & 40.25 & 2.2388 & 13 & 46.9529 & 0.1771 & 51.10 & 0.0018 \\
\hline & 45.5 & 1.9919 & 53 & 56.5666 & 0.2362 & 39.90 & 0.0019 \\
\hline & 47.0 & 1.9318 & 16 & 58.3699 & 0.2952 & 32.21 & 0.0023 \\
\hline & 53.0 & 1.7264 & 11 & 66.3066 & 0.2362 & 41.97 & 0.0016 \\
\hline & 56.5 & 1.6274 & 17 & 75.3659 & 0.2880 & 36.41 & 0.0016 \\
\hline & 58.5 & 1.5765 & 12 & & & & \\
\hline & 66.5 & 1.4049 & 9 & & & & \\
\hline & 68.5 & 1.3687 & 8 & & & & \\
\hline & 75.5 & 1.2582 & 14 & & & & \\
\hline \multirow{7}{*}[\mathrm{Co}(\mathrm{C}_{10}\mathrm{H}_{9}\mathrm{N}_{4}\mathrm{O})_{2}]{$\cdot \mathrm{Cl}$} & 23.5 & 3.7826 & 97 & 31.8958 & 0.1771 & 48.75 & 0.0027 \\
\hline & 32.5 & 2.7527 & 100 & 45.6464 & 0.2362 & 38.13 & 0.0024 \\
\hline & 46.0 & 1.9714 & 71 & 56.6933 & 0.4320 & 21.83 & 0.0035 \\
\hline & 57.0 & 1.6143 & 36 & & & & \\
\hline & 67.0 & 1.3956 & 29 & & & & \\
\hline & 75.5 & 1.2582 & 27 & & & & \\
\hline & 76.75 & 1.2408 & 24 & & & & \\
\hline \multirow{5}{*}[\mathrm{Ni}(\mathrm{C}_{10}\mathrm{H}_{9}\mathrm{N}_{4}\mathrm{O})_{2}]{} & 21.75 & 4.0828 & 100 & 31.7813 & 0.2362 & 36.54 & 0.0036 \\
\hline & 32.0 & 2.7946 & 88 & 45.5279 & 0.2160 & 41.68 & 0.0022 \\
\hline & 46.5 & 1.9514 & 51 & & & & \\
\hline & 57.0 & 1.6143 & 30 & & & & \\
\hline & 75.5 & 1.2582 & 22 & & & & \\
\hline \multirow{7}{*}[\mathrm{Cu}(\mathrm{C}_{10}\mathrm{H}_{9}\mathrm{N}_{4}\mathrm{O})_{2}]{} & 22.75 & 3.9056 & 64 & 31.9043 & 0.1771 & 48.75 & 0.0027 \\
\hline & 32.0 & 2.7946 & 100 & 45.6348 & 0.2362 & 38.13 & 0.0024 \\
\hline & 46.0 & 1.9714 & 57 & 56.6501 & 0.3542 & 26.62 & 0.0029 \\
\hline & 56.75 & 1.6209 & 31 & 75.4511 & 0.4320 & 24.29 & 0.0024 \\
\hline & 66.75 & 1.4002 & 27 & & & & \\
\hline & 70.25 & 1.3388 & 24 & & & & \\
\hline & 75.5 & 1.2582 & 25 & & & & \\
\hline \multirow{7}{*}[\mathrm{Zn}(\mathrm{C}_{10}\mathrm{H}_{9}\mathrm{N}_{4}\mathrm{O})_{2}]{} & 22.0 & 4.0370 & 72 & 31.8421 & 0.1771 & 48.74 & 0.0027 \\
\hline & 31.75 & 2.8160 & 100 & 45.5741 & 0.1771 & 50.84 & 0.0018 \\
\hline & 42.25 & 2.1373 & 31 & 56.6119 & 0.2952 & 31.94 & 0.0024 \\
\hline & 45.5 & 1.9919 & 73 & 75.4110 & 0.4320 & 24.28 & 0.0024 \\
\hline & 56.75 & 1.6209 & 28 & & & & \\
\hline & 66.5 & 1.4049 & 19 & & & & \\
\hline & 75.5 & 1.2582 & 19 & & & & \\
\hline \multirow{7}{*}[\mathrm{Cd}(\mathrm{C}_{10}\mathrm{H}_{9}\mathrm{N}_{4}\mathrm{O})_{2}]{} & 24.25 & 3.6673 & 44 & 31.9590 & 0.2952 & 29.25 & 0.0045 \\
\hline & 32.0 & 2.7946 & 100 & 34.1917 & 0.4723 & 18.39 & 0.0067 \\
\hline & 34.25 & 2.6160 & 35 & 45.6891 & 0.2952 & 30.51 & 0.0031 \\
\hline & 45.75 & 1.9816 & 61 & 56.7272 & 0.2952 & 31.95 & 0.0024 \\
\hline & 56.75 & 1.6209 & 27 & 66.4988 & 0.7085 & 14.01 & 0.0047 \\
\hline & 66.5 & 1.4049 & 19 & 75.5104 & 0.3600 & 29.16 & 0.0020 \\
\hline & 75.5 & 1.2582 & 24 & & & & \\
\hline \multirow{7}{*}[\mathrm{Hg}(\mathrm{C}_{10}\mathrm{H}_{9}\mathrm{N}_{4}\mathrm{O})_{2}]{} & 23.25 & 3.8227 & 100 & 31.8700 & 0.2362 & 36.55 & 0.0036 \\
\hline & 32.25 & 2.7735 & 84 & 45.6097 & 0.3600 & 25.01 & 0.0037 \\
\hline & 41.75 & 2.1618 & 42 & & & & \\
\hline & 45.75 & 1.9816 & 52 & & & & \\
\hline & 56.75 & 1.6209 & 30 & & & & \\
\hline & 59.25 & 1.5583 & 26 & & & & \\
\hline & 75.5 & 1.2582 & 21 & & & & \\
\hline
\end{tabular}


angle and full width at half maximum of an observed peak, respectively [58-60].

SEM analysis: The properties of ligand and its metal complexes like surface morphology, distribution of particles, aggregation and shape of the particles study by scanning electron microscopy (SEM) technique. SEM image (Fig. 5) shows that the ligand (HMePAI) has form of peripheral spherical shape with average size $85 \mathrm{~nm}$ with a ratio of less than aggregation. The SEM of the complexes revealed that the particles are agglomerated and non-uniform particles are observed in some cases. Moreover, SEM micrographs of the metal complexes revealed that the surface morphology of metal complexes is changed by changing the metal ions [61,62]. The calculations of particles size were performed using MagniSci software (Fig. 5). The SEM image of $\mathrm{Cr}$ (III) complex seemed heterogeneous surfaced type average particle size $175 \mathrm{~nm}$. The SEM analysis of $\mathrm{Mn}(\mathrm{II})$ complex appeared in the form of heterogeneous the surface with average particle size $145 \mathrm{~nm}$. The SEM image of $\mathrm{Fe}(\mathrm{III})$ complex appeared in the form of heterogeneous surface with average particle size of $155 \mathrm{~nm}$. As the analysis of SEM
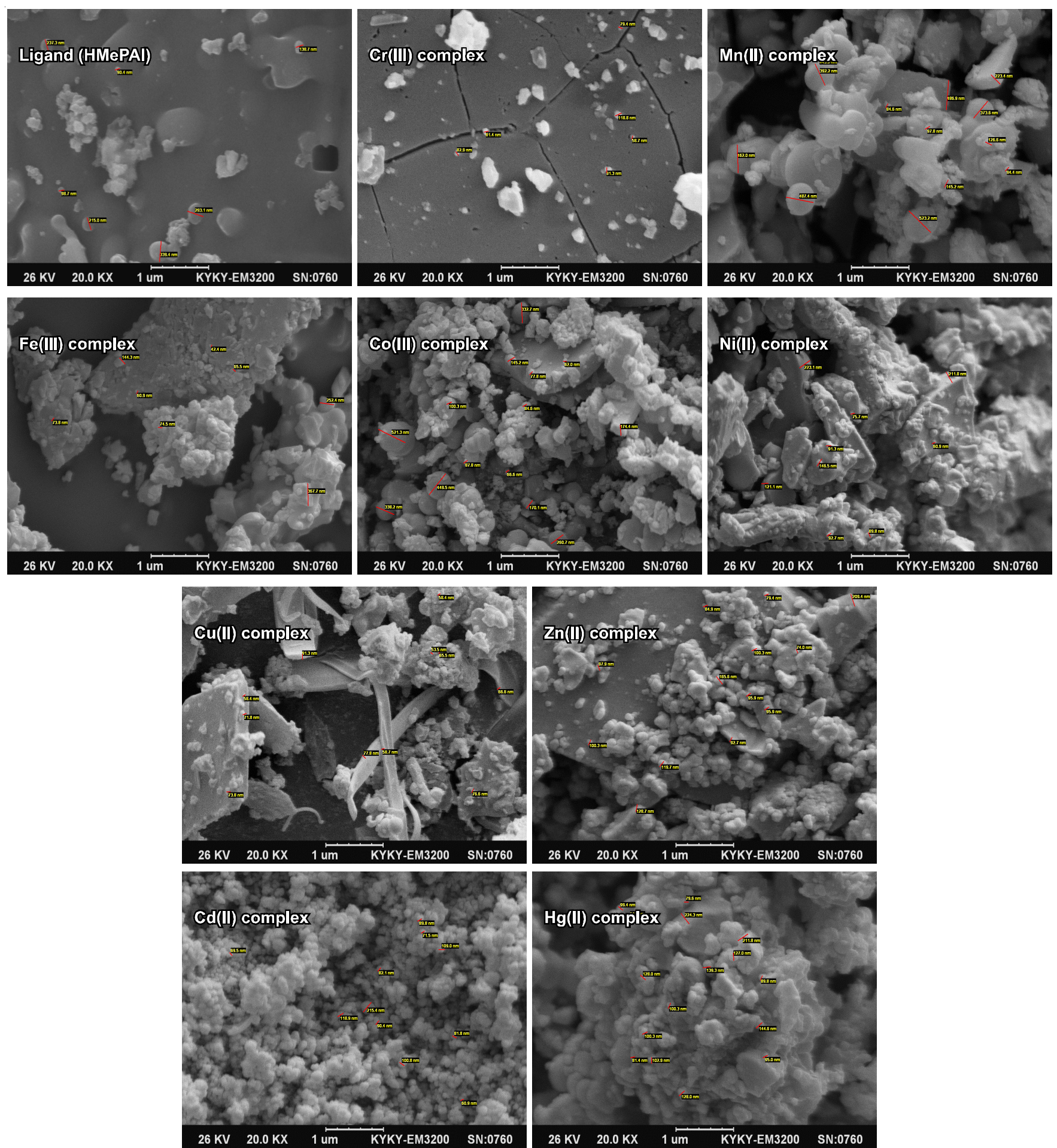

Fig. 5. SEM images of ligand (HMePAI)and prepared metal complexes 
for $\mathrm{Co}(\mathrm{III})$ complex seemed heterogeneous surfaced type with average size of $120 \mathrm{~nm}$. The SEM image for Ni(II) complex appeared in the form of a small particle size is heterogeneous surface and the average particle size of $150 \mathrm{~nm}$, either the analysis of SEM for $\mathrm{Cu}(\mathrm{II})$ appeared in the form of heterogeneous surface and the average particle size $160 \mathrm{~nm}$. The SEM image of $\mathrm{Zn}$ (II) complex seemed heterogeneous surfaced with average particle size $150 \mathrm{~nm}$. The analysis of SEM for complex Cd(II) complex appeared in the form of small particles size heterogeneous surface and the average particle size of $130 \mathrm{~nm}$. The SEM image of $\mathrm{Hg}(\mathrm{II})$ seemed heterogeneous surfaced type with average particle size $125 \mathrm{~nm}$.

Anitbacterial activity: The antibacterial activity of azo dye ligand (HMePAI) and its metal complexes have been tested for in vitro growth inhibitory activity against Gram-positive bacteria: Staphylococcus aureus, Gram-negative bacteria: Escherichia coli by using spots diffusion method. All of tested ligand and its metal complexes show a remarkable antibacterial activity against tested bacteria (Table-7). The Staphylococcus aureus bacteria was of a high activity and sensitivity towards ligand and all metal complexes except the $\mathrm{Cu}(\mathrm{II}), \mathrm{Zn}$ (II) and $\mathrm{Hg}$ (II) complexes which were resistant and inactive while Escherichia coli bacteria which was inactive and not sensitive towards ligand and all metal complexes. The mechanism of action of antibacterial drug can be discussed under four headings: (1): inhibition of cell wall, (2): inhibition of cell membrane function, (3): inhibition of protein prepared and (4): inhibition of nucleic acid [29,63].

Cell viability and cytotoxicity assays: The lines of cancerous liver cells of the type $\mathrm{HePG}_{2}$ are used and compared with line of the ordinary cells. These lines are procured from department of pharmacology/faculty of medicine center for natural product research and drug discovery/University of Malya, Kualalampur, Malaysia. Freshney method is used for the development of the cell of cancerous cell line of the liver $\mathrm{HePG}_{2}$. The data is statistically analyzed by a one way analysis of variance ANOVA (Duncan) was performed to test whether group variance was significant or not. Data were expressed as mean \pm standard error and statistical significances were carried out using SPSS program version 20 and drowned using Graph Pad Prism version 6. The relation between the biological activity of the cancerous line cell of the liver $\mathrm{HePG}_{2}$ and normal line cells of the liver WRL and the concentration of the ligand and its complex with $\mathrm{Ni}$ (II) ion. It is observed that the inhibition of the ligand (HMePAI) differs with difference of cell line where the number of the remaining living cells after the reaction with $\mathrm{Ni}(\mathrm{II})$ complex is about $(99.62,47.07) \%$ for the cancerous cell line of the liver $\mathrm{HePG}_{2}$ and (99.57-90.86) \% for normal cell line WRL. It is observed that the highest ratio of the inhibition of the ligand for the cancerous cell line of the liver $\mathrm{HePG}_{2}$ is $47.07 \%$ whereas the ratio of the normal cell line
WRL is $99.86 \%$ for the living cells and this indicates that $\mathrm{Ni}$ (II) complex has a higher efficiency than the ligand inhibiting the growth of cancerous cells. The reason behind this inhibition of the growth of cancer cell is that the ligand and $\mathrm{Ni}(\mathrm{II})$ complex include imidazole ring which has a high efficiency in inhibiting or stopping the growth of cancer cells. Moreover, increasing the efficiency in inhibiting the growth of cancer cells by using $\mathrm{Ni}$ (II) complex is more than that in the ligand because it includes two imidazole rings. These kind of imidazole compounds are used in treating blood cancer, lung cancer, hepatomegaly and breast cancer $[64,65]$.

The results show also that the type of compound and its concentration has an essential role in determining the ratio of inhibiting the growth of cancer cells depending on the dose which increases the inhibition by increasing the concentration to certain limits where the lesser the concentration the material, the easier it is to penetrate the outer membrane of the cells, but not to limit the dilution which loses its effectiveness.

Also it has been found through the tests conducted on ligand and its complex with $\mathrm{Ni}$ (II) ion to know inhibition concentration $\mathrm{IC}_{50}$, that in case of using ligand, it kills half of infected cells and its effect will be lesser on the non-infected cells because it needs high concentration for its half to be killed, i.e. it is about four times of the concentration required to kill cancerous cells. In case of $\mathrm{Ni}(\mathrm{II})$ complex, it is observed that $\mathrm{IC}_{50}$ is not within concentration used and this can be considered an excellent result, the $\mathrm{Ni}$ (II) complex kills the cancerous cells and its effect is imperceptible on the normal cells because they need very high concentration in order for their half to be killed where it reaches approximately three hundred times required to kill half of the cancerous cells. This is an important and new result in our study. Table- 8 show the results mentioned above. Through assays conducted to identify the possibility of using the ligand (HMePAI) and Ni(II) complex anticancer drugs.

\section{Conclusion}

In the present study, the synthesis, spectral and thermal analyses of $\mathrm{Cr}(\mathrm{III}), \mathrm{Mn}(\mathrm{II}), \mathrm{Fe}(\mathrm{III}), \mathrm{Co}(\mathrm{III}), \mathrm{Ni}(\mathrm{II}), \mathrm{Cu}(\mathrm{II})$, $\mathrm{Zn}(\mathrm{II}), \mathrm{Cd}(\mathrm{II})$ and $\mathrm{Hg}$ (II) complexes of aryl azo imidazole ligand (HMePAI) have been carried out. The azo dye ligand (HMePAI) acts as neutral tridentate coordinating through phenolic oxygen, nitrogen of azo group $\left(\mathrm{N}_{3}\right)$ which is the farthest of imidazole ring and nitrogen of imidazole ring (N3) to form two five membered metal rings. On the basis of their analytical and spectral data, we propose octahedral geometry for metal complexes. The ligand and its metal complexes different morphologies as appeared in XRD and SEM studies. The ligand and its metal complexes are found to have higher biological activities. Also, the study of ligand and Ni(II)-complex in cells viability and cytotoxicity assays by using the lines of cancerous liver cells, of the type HePG2 and compared with line of the

TABLE-7

ANTIBACTERIAL ACTIVITY DATA (ZONE OF INHIBITION IN mm) OF AZO DYE LIGAND (HMePAI) AND ITS METAL COMPLEXES

\begin{tabular}{ccccccccccc}
\hline Compounds & HMePAI & $\mathrm{Cr}(\mathrm{III})$ & $\mathrm{Mn}(\mathrm{II})$ & $\mathrm{Fe}(\mathrm{III})$ & $\mathrm{Co}(\mathrm{III})$ & $\mathrm{Ni}(\mathrm{II})$ & $\mathrm{Cu}(\mathrm{II})$ & $\mathrm{Zn}(\mathrm{II})$ & $\mathrm{Cd}(\mathrm{II})$ & $\mathrm{Hg}(\mathrm{II})$ \\
\hline S. aureus & +++ & +++ & +++ & +++ & +++ & +++ & - & - & +++ & - \\
E. coli & $21 \mathrm{~mm}$ & $16.5 \mathrm{~mm}$ & $15.5 \mathrm{~mm}$ & $15.0 \mathrm{~mm}$ & $17 \mathrm{~mm}$ & $17.5 \mathrm{~mm}$ & $0 \mathrm{~mm}$ & $0 \mathrm{~mm}$ & $17 \mathrm{~mm}$ & $0 \mathrm{~mm}$ \\
\hline & - & - & - & - & - & - & - & - & -+ & - \\
\hline
\end{tabular}

Note: Highly active $=+++$ Inhibition zone $>12 \mathrm{~mm}$ 


\begin{tabular}{|c|c|c|c|c|c|}
\hline \multirow[b]{3}{*}{ S. No. } & \multicolumn{5}{|c|}{$\begin{array}{l}\text { TABLE-8 } \\
\text { RELATION BETWEEN INHIBITION CONCENTRATION (IC }{ }_{50} \text { ) AND CELL } \\
\text { VIABILITY/CYTOTOXICITY FOR LIGAND (HMePAI) AND Ni(II) COMPLEX }\end{array}$} \\
\hline & \multirow[b]{2}{*}{ Non-linear fitting } & \multicolumn{2}{|c|}{ Ligand (HMePAI) } & \multicolumn{2}{|c|}{$\mathrm{Ni}(\mathrm{II})$ complex } \\
\hline & & $\begin{array}{c}\text { Cancerous line cells of } \\
\text { liver } \mathrm{HePG}_{2}\end{array}$ & $\begin{array}{c}\text { Normal line cells of } \\
\text { liver WRL }\end{array}$ & $\begin{array}{c}\text { Cancerous line cells of } \\
\text { liver } \mathrm{HePG}_{2}\end{array}$ & $\begin{array}{c}\text { Normal line cells of } \\
\text { liver WRL }\end{array}$ \\
\hline 1 & $\begin{array}{l}\log \text { (inhibitor) vs. response } \\
\text { (three parameters) }\end{array}$ & & & & Ambiguous \\
\hline 2 & Best-fit values & & & & \\
\hline 3 & Bottom & -30.76 & -4.703 & -25.55 & $\sim-2426$ \\
\hline 4 & Top & 112.2 & 101.5 & 107.3 & 98.17 \\
\hline 5 & $\log \mathrm{IC}_{50}$ & 2.477 & 3.092 & 2.678 & $\sim 5.154$ \\
\hline 6 & $\mathrm{IC}_{50}$ & 299.9 & 1236 & 476.2 & $\sim 142711$ \\
\hline 7 & Span & 143.0 & 106.2 & 132.8 & $\sim 2524$ \\
\hline 8 & Std. Error & & & & \\
\hline 9 & Bottom & 17.38 & 192.7 & 25.56 & $\sim 1.449 \mathrm{e}+006$ \\
\hline 10 & Top & 3.433 & 3.380 & 2.396 & 2.259 \\
\hline 11 & $\log \mathrm{IC}_{50}$ & 0.1213 & 1.057 & 0.1544 & $\sim 250.0$ \\
\hline 12 & Span & 15.08 & 190.2 & 23.86 & $\sim 1.449 \mathrm{e}+006$ \\
\hline 13 & $95 \%$ confidence Intervals & & & & \\
\hline 14 & Bottom & -105.5 to 44.02 & -833.9 to 824.5 & -135.5 to 84.44 & (Very wide) \\
\hline 15 & Top & 97.44 to 127.0 & 86.96 to 116.0 & 96.97 to 117.6 & 88.45 to 107.9 \\
\hline 16 & $\log \mathrm{IC}_{50}$ & 1.955 to 2.999 & -1.454 to 7.638 & 2.013 to 3.342 & (Very wide) \\
\hline 17 & $\mathrm{IC}_{50}$ & 90.16 to 997.4 & 0.03512 to $4.348 \times 10^{7}$ & 103.1 to 2199 & (Very wide) \\
\hline 18 & Span & 78.08 to 207.9 & -712.2 to 924.6 & 30.14 to 235.5 & (Very wide) \\
\hline 19 & Goodness of fit & & & & \\
\hline 20 & Degrees of freedom & 2 & 2 & 2 & 2 \\
\hline 21 & $\mathrm{R}$ square & 0.9970 & 0.9566 & 0.9967 & 0.7561 \\
\hline 22 & Absolute Sum of Square & 9.832 & 16.96 & 6.257 & 9.329 \\
\hline 23 & Sy.x & 2.217 & 2.912 & 1.769 & 2.160 \\
\hline 25 & Number of points & & & & \\
\hline 26 & Analyzed & 5 & 5 & 5 & 5 \\
\hline
\end{tabular}

ordinary cells, through tests conducted to identify the possibility of using the ligand and $\mathrm{Ni}(\mathrm{II})$-complex anticancer drug.

\section{REFERENCES}

1. P.M. Savanor, S.K. Bhat and R.N. Tantry, Res. J. Chem. Sci., 3, 38 (2013).

2. A. Khosravi, S. Moradian, K. Gharaning and F.A. Taromi Dyes Pigments, 69, 79 (2006);

https://doi.org/10.1016/j.dyepig.2005.02.007.

3. Y.K. Gupta and S. Agarwal, Res. J. Chem. Sci., 2, 68 (2012).

4. D.R. Waring and G. Hallas, The Chemistry and Application of Dyes, Plenum Press, New York and London (1990).

5. M.S. Bashandy, F.A. Mohamed, M.M. El-Molla, M.B. Sheier and A.H. Bedair, Open J. Med. Chem., 6, 18 (2016);

https://doi.org/10.4236/ojmc.2016.61002.

6. K.J. Al-Adilee and H.K. Dakhil, J. Al-Qadisiya Pure Sci., 16, 94 (2011).

7. K. Komatsu and N. Kuroki, J. Soc. Chem. Ind. Jpn., 73, 2190 (1970); https://doi.org/10.1246/nikkashi1898.73.10 2190.

8. M. Hranjec, K. Starcevic, S.K. Pavelic, P. Lucin, K. Pavelic and G.K. Zamola, Eur. J. Med. Chem., 46, 2274 (2011); https://doi.org/10.1016/i.ejmech.2011.03.008.

9. M. Hranjec, G. Pavlovic and G.K. Zamola, J. Mol. Struct., 1007, 242 (2012); https://doi.org/10.1016/j.molstruc.2011.10.054.

10. K.F. Ansari and C. Lal, Eur. J. Med. Chem., 44, 4028 (2009); https://doi.org/10.1016/j.ejmech.2009.04.037.

11. N.S. Pawar, D.S. Dalal, S.R. Shimpi and P.P. Mahulikar, Eur. J. Pharm. Sci., 21, 115 (2004);

https://doi.org/10.1016/j.ejps.2003.09.001.

12. A. Mohammadi, B. Khalili and M. Tahavor, Spectrochim. Acta A Mol. Biomol. Spectrosc., 150, 799 (2015); https://doi.org/10.1016/j.saa.2015.06.024.

13. K. Kubo, Y. Kohara, Y. Yoshimura, Y. Inada, Y. Shibouta, Y. Furukawa, T. Kato, K. Nishikawa and T. Naka, J. Med. Chem., 36, 2343 (1993); https://doi.org/10.1021/jm00068a011.
14. W.W.K.R. Mederski, D. Dorsch, S. Anzali, J. Gleitz, B. Cezanne and C. Tsaklakidis, Bioorg. Med. Chem. Lett., 14, 3763 (2004); https://doi.org/10.1016/j.bmcl.2004.04.097.

15. H. Park, E.-R. Kim, D.J. Kim and H. Lee, Bull. Chem. Soc. Jpn., 75, 2067 (2002); https://doi.org/10.1246/bcsj.75.2067.

16. K.I. Birkett and P. Gregory, Dyes Pigments, 7, 341 (1986); https://doi.org/10.1016/0143-7208(86)80002-X

17. R.H. Sprague, US Patent 289238 (1959).

18. I.Q. Prager and R.H. Sprague, Photographic Sensitizing Dyes Derived from 2-Alkyl-5,6-dihydro-4H-pyrano(3, 2d) thiazole, US Patent 2886565 (1959).

19. K. Bredereck, Dyes Pigments, 21, 23 (1993); https://doi.org/10.1016/0143-7208(93)85003-I.

20. G.M. Malik and S.K. Zadafiya, Der Chem. Sinica, 1, 15 (2010).

21. H. Teranishi, K. Takagawa, Y. Arai, K. Wakaki, Y. Sumi and K. Takaya, J. Occup. Health, 44, 60 (2002); https://doi.org/10.1539/joh.44.60

22. A. Nandi, C. Sen, D. Mallick, R.K. Sinha and C. Sinha, Adv. Mater. Phys. Chem., 3, 133 (2013); https://doi.org/10.4236/ampc.2013.32019.

23. K.J. Al-Adilee, Asian J. Chem., 24, 5597 (2012).

24. K.J. Al-Adilee, H.A. Habeeb and M.N. Dawood, Res. J. Pharma. Bio. Chem. Sci., 7, 2882 (2016).

25. A.I. Vogel, A Text Book of Quantitative Inorganic Analysis, Longman ELBS, London, edn 3 (1968).

26. K.J. Al-Adilee, Res. J. Pharm. Bio. Chem. Sci., 6, 1297 (2015).

27. K.J. Al-Adilee, K.A. Abedalrazaq and Z.M. Al-Hamdiny, Asian J. Chem., 25, 10475 (2013); https://doi.org/10.14233/ajchem.2013.15735.

28. K.J. Al-Adilee and D.Y. Fanfon, J. Chem. Chem. Eng., 6, 1016 (2012); https://doi.org/10.17265/1934-7375/2012.11.011.

29. J.Z. Mohammed, H. Abbas and A.A.M. Ali, Int. J. Curr. Res., 5, 3705 (2013).

30. H. Irving and R.J.P. Williams, J. Chem. Soc., 3192 (1953); https://doi.org/10.1039/jr9530003192.

31. K.J. Al-Adilee, Iraqi Nat. J. Chem. J. Chem., 28, 585 (2007). 
32. M.B. Halli, K. Mallikarjun and S. Sadusuryakant, J. Chem. Pharm. Res., 7, 1797 (2015)

33. K.J. Al-Adilee and H.A.K. Kyhoiesh, J. Mol. Struct., 1137, 160 (2017); https://doi.org/10.1016/j.molstruc.2017.01.054.

34. M. Ozkutuk, E. Ipek, B. Aydiner, S. Mamas and Z. Seferoglu, J. Mol. Struct., 1108, 521 (2016); https://doi.org/10.1016/j.molstruc.2015.12.032.

35. K.J. Al-Adilee and B.A. Hatam, J. Adv. Chem., 3, 3412 (2015).

36. A.A. El-Bindary, G.G. Mohamed, A.Z. El-Sonbati, M.A. Diab, W.M.I. Hassan, Sh.M. Morgan and A.K.Elkholy, J. Mol. Liq., 218, 138 (2016); https://doi.org/10.1016/j.molliq.2016.02.021.

37. R. Mahmoud, A.M. Hammam, S.A. El-Gyar and S.A. Ibrahim, Monatsh. Chem., 117, 313 (1986); https://doi.org/10.1007/BF00816525.

38. Y. Yildiz, M.K. M. Keles, A.K. A. Kaya and S.D. S. Dincer, Chem. Sci. Trans., 2, 547 (2013); https://doi.org/10.7598/cst2013.353.

39. S. Saha, T. Majumdar and Mahapatra, Transition Met. Chem, 31, 1017 (2006); https://doi.org/10.1007/s11243-006-0101-6.

40. S. Chandra, M. Tyagi and K. Sharma, J. Iran. Chem. Soc., 6, 310 (2009); https://doi.org/10.1007/BF03245839.

41. L. Mangsup, S. Siripaisarnpipat and N. Chaichit, Anal. Sci., 19, 1345 (2003); https://doi.org/10.2116/analsci.19.1345.

42. K. Dey and K.K. Nandi, Indian J. Chem., 35A, 766 (1996).

43. J. C. Bailer, H. Emeleus and R. Nypholm, Comprehensive Inorganic Chemistry, Pergamon Press (1973).

44. S. Rao and K.H. Reddy, Indian J. Chem., 35A, 681 (1996).

45. T.K. Pal and C. Sinha, Proc. Indiana Acad. Sci., 113, 173 (2001); https://doi.org/10.1007/BF02704067.

46. O. Yamauchi, Talanta, 15, 177 (1968); https://doi.org/10.1016/0039-9140(68)80220-6.

47. B.B. Mahapatra and S.K. Pujari, Transition Met. Chem., 8, 202 (1983); https://doi.org/10.1007/BF00620688.

48. C.J. Ballhausen, Introduction to Ligand Field Theory, McGraw-Hill, New York (1962)

49. M. Kurahashi, Bull. Chem. Soc. Jpn., 47, 2067 (1974); https://doi.org/10.1246/bcsj.47.2067.
50. P.K. Ghosh, S. Saha and A. Mahapatra, Chem. Cent. J., 1, 23 (2007); https://doi.org/10.1186/1752-153X-1-23.

51. G. Valamary and R. Subbalaksmi, Indian J. Appl. Res., 3, 43 (2013).

52. R.L. Dutta and A. Syamal, Elements of Magneto Chemistry, Affiliated East West Press, New Delhi, p. 101 (1993).

53. E. Helen, P. Bai and S. Vairam, Asian J. Chem., 25, 209 (2013); https://doi.org/10.14233/ajchem.2013.12895.

54. M. Arshad, Saeed-ur-Rehman, A.H. Qureshi, K. Masud, M. Arif, A. Saeed and R. Ahmed, Turk. J. Chem., 32, 593 (2008).

55. E.T.G. Cavalheiro, F.C.D. Lemos, J.Z. Schpector and E.R. Dockal, Thermochim. Acta, 370, 129 (2001); https://doi.org/10.1016/S0040-6031(00)00777-2.

56. I. Kolthoff, Treatise of Analytical Chemistry, Interscience, New York, Part I, pp 745 (1959).

57. Powder Diffraction file, Inorganic, Published by the Joint Committee on Powder Diffraction Standard, vol. 1,No. PDIS 10Irb:662 (1967).

58. V.S. Gavhane, A.S. Rajbhoj and S.T. Gaikwad, Pharmachem., 8, 275 (2016).

59. R.M.A.Q. Jamhour, Can. Chem. Trans., 2, 306 (2014); https://doi.org/10.13179/canchemtrans.2014.02.03.0111.

60. M.I. Abou-Dobara, A.Z. El-Sonbati, M.A. Diab, A.A. El-Bindary and S.M. Morgan, J. Microb. Biochem. Technol., S3, 06 (2014); https://doi.org/10.4172/1948-5948.S3-006.

61. M. Montazerozohori, S.M. Jahromi and A. Naghiha, J. Ind. Eng. Chem., 22, 248 (2014); https://doi.org/10.1016/j.jiec.2014.07.017.

62. M. Shakir, S. Hanif, M.A. Sherwani, O. Mohammad and S.I. Al-Resayes, J. Mol. Struct., 1092, 143 (2015); https://doi.org/10.1016/j.molstruc.2015.03.012.

63. E. Jawetz, J.L. Melnick and E.A. Adelbrerg, Medical Microbiology, McGraw Hill, USA, edn 24 (2007).

64. F. Bellina, S. Cauteruccio, A. Di Fiore and R. Rossi, Eur. J. Org. Chem., 2008, 5436 (2008); https://doi.org/10.1002/ejoc.200800738.

65. F. Li, J. Cui, L. Guo, X. Qian, W. Ren, K. Wang and F. Liu, Bioorg. Med. Chem., 15, 5114 (2007);

https://doi.org/10.1016/j.bmc.2007.05.032. 